Instytut Archeologii

Uniwersytet Mikołaja Kopernika

$w$ Toruniu

Magdalena Sudoł, Krzysztof Cyrek

\title{
OSADNICTWO PALEOLITYCZNE NA WYŻYNIE RYCZOWSKIEJ (ŚRODKOWA CZĘŚĆ WYŻYNY CZĘSTOCHOWSKIEJ)
}

Zarys treści. Artykuł omawia zagadnienie osadnictwa paleolitycznego na Wyżynie Ryczowskiej w oparciu o wyniki interdyscyplinarnych badań. Stanowi on przyczynek do rozważań nad relacjami między człowiekiem a niektórymi aspektami uwarunkowań środowiskowych w paleolicie.

Słowa kluczowe: osadnictwo paleolityczne, wyroby krzemienne, wyroby kościane, Wyżyna Ryczowska, Wyżyna Częstochowska.

\section{WSTĘP}

Rozpoznanie charakteru i uwarunkowań osadnictwa społeczności pradziejowych jest jednym z kluczowych zadań jakie stawia sobie badacz epoki kamienia. Podstawową procedurę badawczą stanowi szczegółowa analiza stanowisk archeologicznych. Niezwykle ważne jest także dokładne poznanie przestrzeni wokół nich, jako zaplecza warunkującego rozwój społeczny i kulturowy.

Podjęty przez autorów temat jest rozwinięciem zagadnienia penetracji przestrzeni osadniczej w bezpośrednim sąsiedztwie Jaskini Biśnik w okresie paleolitu (Sudoł i in. 2016), a tym samym próbą syntetycznej prezentacji osadnictwa paleolitycznego całego mikroregionu Wyżyny Ryczowskiej (środkowa część Wyżyny Częstochowskiej). Z dużym prawdopodobieństwem był to obszar wyjątkowo korzystny pod względem zasiedlenia w okresie paleolitu. Charakterystyczne dla niego są systemy rozgałęzionych obniżeń dolinnych, które rozdzielają wyraźnie zaznaczone wzniesienia. W okresie środkowego i późnego plejstocenu paleolityczny łowca dysponował w tym rejonie różnorodnymi, niezbędnymi do życia zasobami, tj. pożywieniem (wędrujące dolinami zwierzęta), wodą (rzeki, jeziora i źródła krasowe), schronieniem 
(jaskinie i schroniska skalne) oraz surowcem do produkcji narzędzi i broni łowieckiej (wychodnie jurajskich wapieni ze złożami zróżnicowanych surowców krzemiennych dobrej jakości) (Krajcarz, Krajcarz i in. 2012; Krajcarz, Sudoł i in. 2012a; 2014).

Prace badawcze nad starszą epoką kamienia na Wyżynie Ryczowskiej skupiały się w ostatnich dwóch dekadach na stanowiskach w rejonie doliny Wodącej, przede wszystkim na środkowopaleolitycznym stanowisku w Jaskini Biśnik (Cyrek i in. 2010; 2014) oraz w rejonie Skał Kroczyckich (Cyrek 2009). W oparciu o wyniki badań prowadzonych w ostatnich latach rysuje się szerszy obraz zasiedlenia, uwzględniający południową część Wyżyny Ryczowskiej.

Artykułjestprzyczynkiem dorozważańnad relacjamimiędzy człowiekiem a niektórymi aspektami środowiska przyrodniczego w kolejnych fazach paleolitu, na podstawie danych pochodzących z kilku stanowisk zlokalizowanych na Wyżynie Ryczowskiej, w mikroregionach: doliny Wodącej ${ }^{1}$, doliny Udorki ${ }^{2}$, Skał Kroczyckich i Podlesickich oraz Pasma Ogrodzienieckiego (ryc. 1).

\section{STAN WIEDZY W ZAKRESIE TEMATU BADAŃ}

Pierwsze badania w północnej części Wyżyny Ryczowskiej można przypisać Leonowi Kozłowskiemu. Na podstawie źródeł wiemy, że w roku 1917 rozpoczął on intensywną penetrację jaskiń Jury Północnej (Kowalski 1951; Kozłowski 2007), między innymi w rejonie miejscowości Rzędkowice, Kroczyce i Podlesice (Cyrek 2009). Następnie, w latach 1952-1956, prace w tym rejonie podjął Waldemar Chmielewski z żoną Marią, którzy przebadali między innymi Schronisko Ruska Skała i Jaskinię Dziadowa Skała (Chmielewska, Pierzchałko 1956; Chmielewski 1958). Prace w rejonie Skał Podlesickich kontynuował w 1989 roku Krzysztof Cyrek, weryfikując Ruską Skałę (Cyrek 2009), zaś w latach 1989-1998 prowadząc badania w Skałach Kroczyckich, tj. w schroniskach: Krucza Skała i na Górze Słupsko oraz w jaskiniach: Desz-

\footnotetext{
${ }^{1}$ Badania w Jaskini Biśnik, były finansowane z grantu Ministerstwa Nauki i Szkolnictwa Wyższego nr NN 109318237 pt. „Przyrodnicze i kulturowe aspekty środkowopaleolitycznego osadnictwa w Jaskini Biśnik", a badania w Schronisku nad Jaskinią Zegar oraz Schronisku w Smoleniu III z grantu Narodowego Centrum Nauki nr 2011/01/N/HS3/01299 pt. „Osadnictwo paleolityczne doliny Wodącej i doliny Udorki (Wyżyna Ryczowska) na tle uwarunkowań paleośrodowiskowych".

${ }^{2}$ Badania w Jaskini Perspektywicznej, były finansowane z grantu Narodowego Centrum Nauki nr 2011/01/N/HS3/01299 pt. „Osadnictwo paleolityczne doliny Wodącej i doliny Udorki (Wyżyna Ryczowska) na tle uwarunkowań paleośrodowiskowych”.
} 


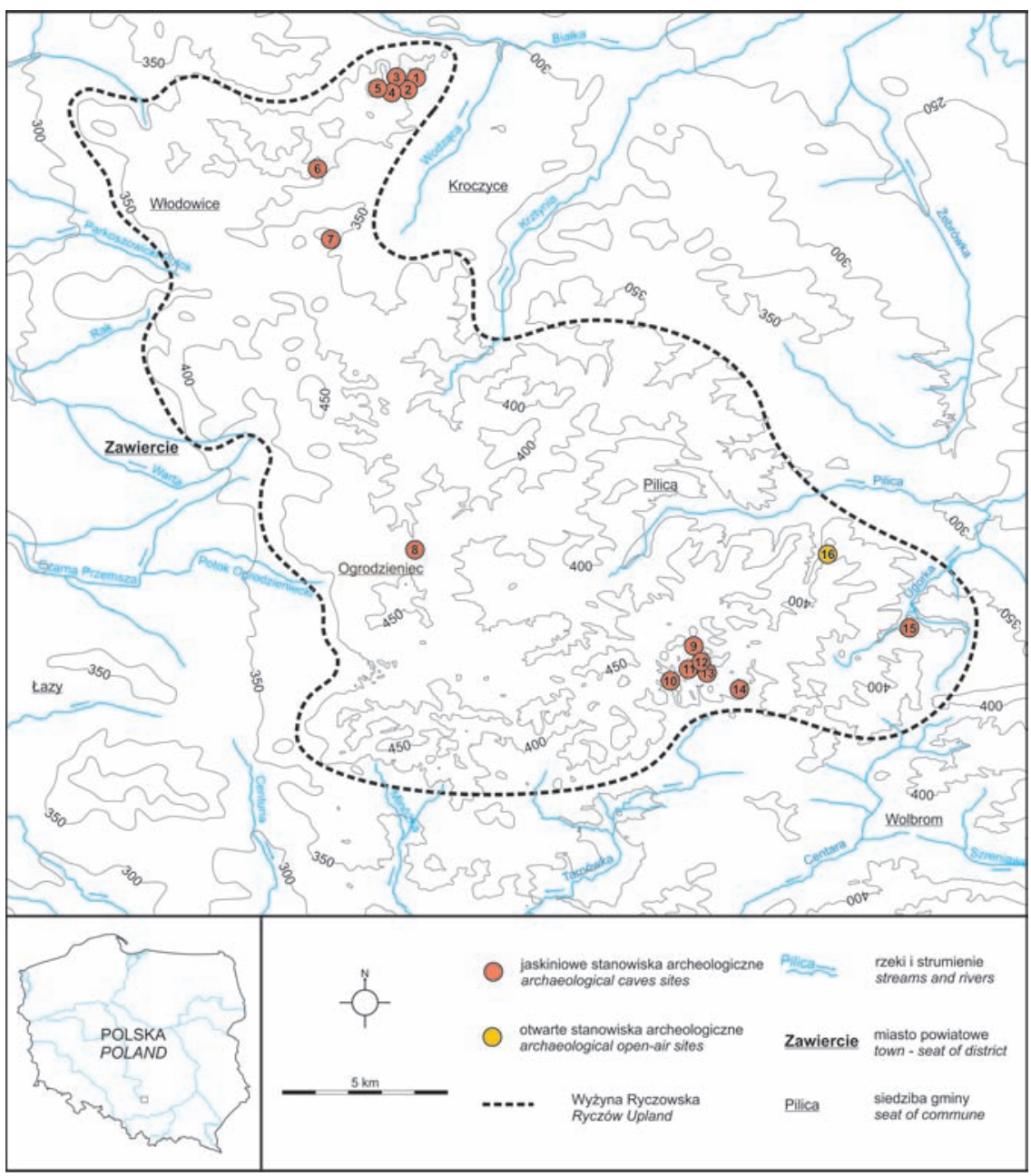

Ryc. 1. Stanowiska paleolityczne na Wyżynie Ryczowskiej: 1 - Schronisko na Górze Słupsko; 2 - Schronisko Krucza Skała; 3 - Jaskinia Deszczowa; 4 - Jaskinia Kroczycka; 5 - Jaskinia Złodziejska; 6 - Schronisko Ruska Skała; 7 - Jaskinia Dziadowa Skała; 8 - Schronisko IV Północne w Górze Birów; 9 - Schronisko w Smoleniu III; 10 - Jaskinia Biśnik; 11 - Schronisko nad Jaskinią Zegar; 12 - Jaskinia Zegarowa Dolna; 13 - Jaskinia Jasna Smoleńska; 14 - Jaskinia Jasna Strzegowska; 15 - Jaskinia Perspektywiczna z kompleksem pobliskich schronisk; 16 - kompleks stanowisk otwartych w Górach Barańskich (rys. M. Sudoł, M. T. Krajcarz)

Fig. 1. Paleolithic sites in Ryczów Upland: 1 - Shelter in Mt. Słupsko; 2 - Shelter in Krucza Skała; 3 - Deszczowa Cave; 4 - Kroczycka Cave; 5 - Złodziejska Cave; 6 - Shelter in Ruska Skała; 7 - Dziadowa Skała Cave; 8 - Shelter in Mt. Birów IV; 9 - Shelter in Smoleń III; 10 - Biśnik Cave; 11 - Shelter above the Zegar Cave; 12 - Zegarowa Dolna Cave; 13 - Jasna Smoleńska Cave; 14 - Jasna Strzegowska Cave; 15 - Perspektywiczna Cave with a complex of shelters; 16 - complex of open-air sites in Barańskie Mountains (drawn M. Sudoł, M. T. Krajcarz) 
czowej, Złodziejskiej oraz Kroczyckiej (Cyrek 1994a; 1994b; 1994c; 1997; Cyrek i in. 2000). W roku 2011 badania przy współudziale K. Cyrka w jaskiniach: Deszczowej i Nad Bramą Słupską, prowadzili Magdalena i Maciej Krajcarz (Krajcarz, Wojenka i in. 2014).

Badania południowej części Wyżyny Ryczowskiej zapoczątkował Kazimierz Kowalski, który w latach 1942-1949 prowadził prace inwentaryzacyjne obiektów skalnych. Ich wyniki opublikował w pierwszym tomie katalogu „Jaskinie Polski” (Kowalski 1951). Po II wojnie światowej badania archeologiczne w tym rejonie rozpoczął Ludwik Sawicki; w latach 1947-1950 rozpoznał on częściowo dwa duże obiekty: Jaskinię Jasną Smoleńską oraz Jaskinię Jasną Strzegowską (Sawicki 1953). Po długiej przerwie, w roku 1990, prace w południowej części Wyżyny Ryczkowskiej, w rejonie wzgórza Grodzisko Pańskie prowadził Błażej Muzolf (1997a; 1997b). W 1997 roku wraz z zespołem paleozoologów kierowanym przez Teresę Wiszniowską rozpoczął on także badania w rejonie Skał Zegarowych (Muzolf i in. 1999; Stefaniak i in. 2009) i Skały Biśnik (Muzolf 1997c). W latach 1991-1999 B. Muzolf badał również wielokulturowy kompleks stanowisk na Górze Birów w Podzamczu w rejonie Pasma Ogrodzienieckiego (środkowa część Wyżyny Ryczowskiej) (Muzolf 1994; 1997d; 1997e; Muzolf i in. 2009). W latach 90. XX wieku prace archeologiczne obszaru nad Jaskinią Jasną Strzegowską oraz w rejonie Gór Barańskich prowadził Andrzej Pelisiak (Pelisiak 2003; 2006). W roku 1991 wykonał on także sondaż przed wejściem do Jaskini Biśnik (Pelisiak 1993-1994). Od początku lat 90. prace w tym regionie prowadzi K. Cyrek, który w 1991 roku kontynuował badania w Jaskini Jasnej Strzegowskiej (Rybicka, Cyrek 1997), a od roku 1992 do dzisiaj kieruje interdyscyplinarnym zespołem badającym Jaskinię Biśnik (Jaskinia Biśnik 2002; 2013; Cyrek i in. 2010; 2014).

Jak wynika z powyższego przeglądu, badania w południowej części Wyżyny Ryczowskiej skupione były na nielicznych i stosunkowo dużych jaskiniach. Należy jednak podkreślić, że właśnie małe obiekty, takie jak schroniska i nawisy, były bardzo często zasiedlane w paleolicie i są atrakcyjne pod względem pozyskiwanych informacji paleośrodowiskowych, czego dowodzą choćby odkrycia w Skałach Kroczyckich (Cyrek 1994b; 2009; Cyrek i in. 2000), czy w Ojcowskim Parku Narodowym (Dolina Sąspowska i Dolina Prądnika) (Chmielewski 1975; 1988; Madeyska 2006).

Podjęte między innymi przez autorów niniejszego artykułu prace, prowadzone w latach 2011-2014 w ramach projektu pt. „Osadnictwo paleolityczne Doliny Wodącej i Doliny Udorki (Wyżyna Ryczowska) na tle uwarunkowań paleośrodowiskowych", przyniosły odkrycie stanowisk, których poziomy 
kulturowe łączyć można z kolejnymi fazami paleolitu (Sudoł, Cyrek i in. 2013; Sudoł i in. w druku). Wśród nich wyróżnia się Jaskinia Perspektywiczna w dolinie Udorki (Sudoł, Krajcarz, Krajcarz 2013).

\section{WYNIKI BADAŃ}

\section{Środkowy paleolit}

Najstarsze ślady pobytu człowieka neandertalskiego na Wyżynie Ryczowskiej zadokumentowano w jej południowej części, w jaskini Biśnik (ryc. 2). Stanowisko położone jest na lewym brzegu suchej obecnie doliny Wodącej. Zachowany profil osadów składa się z warstw datowanych od okresu poprzedzającego zlodowacenie Odry aż do holocenu (Jaskinia Biśnik 2002; Cyrek 2013; Cyrek i in. 2010; Krajcarz, Bosák i in. 2014).

Najwcześniejsze ślady osadnictwa paleolitycznego sięgają ponad 400000 lat i nawiązują do tradycji aszelskiej (Krajcarz, Cyrek 2011; Cyrek 2013), natomiast późniejsza, środkowopaleolityczna sekwencja zasiedlenia jaskini związana jest mustierskimi i mikockimi poziomami kulturowymi (ryc. 3). Ślady tych poziomów zachowały się w postaci koncentracji kamiennych i kościanych wyrobów, reliktów palenisk oraz fragmentów kości zwierzęcych o pokonsumpcyjnym charakterze (Cyrek i in. 2014).

Relikty środkowopaleolitycznych poziomów kulturowych znane są również z dwóch innych jaskiń, położonych na zboczu doliny Wodącej w kompleksie Skał Zegarowych, tj. Jaskini Zegarowej Dolnej (ryc. 4) (Muzolf, Śnieszko, Wiszniowska 1999; Stefaniak i in. 2009) i Jaskini Jasnej Smoleńskiej (ryc. 5) (Muzolf, Śnieszko, Wiszniowska 1999; Mirosław-Grabowska, Cyrek 2009). Badania w Jaskini Zegarowej Dolnej dowodzą, że zamieszkiwana była przynajmniej kilkakrotnie, a najstarsze ślady człowieka należy wiązać, na podstawie interpretacji klimatostratygraficznych, z późnymi fazami paleolitu środkowego (50-60 tys. lat) (Stefaniak i in. 2009). Były to drobne narzędzia wykonane $\mathrm{z}$ odłupków: między innymi narzędzie z dookolnym retuszem wnękowo-zębatym, fragment narzędzia z odłupka lewaluaskiego i odłupek lewaluaski. Pozyskany inwentarz zaklasyfikowany został do kompleksu mikockiego, głównie na podstawie analogicznej pozycji stratygraficznej do pobliskiej Jaskini Biśnik (Muzolf, Śnieszko, Wiszniowska 1999). Sondaże wykonane wewnątrz Jaskini Jasnej Smoleńskiej ujawniły obecność w głębszych warstwach nielicznych odłupków i łusek krzemiennych w towarzystwie kości nosorożca włochatego i renifera. Nieliczne odłupki znajdowały się 


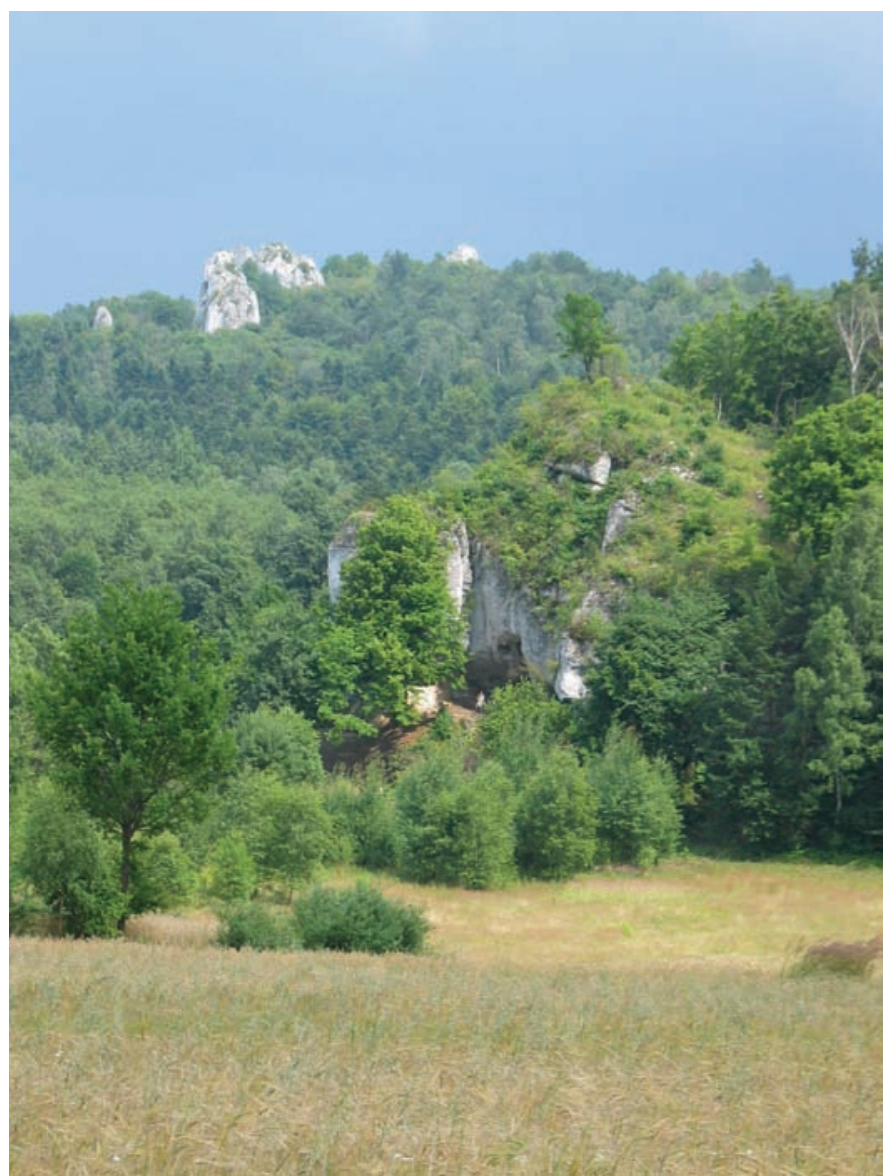

Ryc. 2. Jaskinia Biśnik; widok od strony doliny (fot. M. Sudoł)

Fig. 2. Biśnik Cave; view from the valley side (photo M. Sudoł)

także na zewnątrz jaskini i prawdopodobnie zostały wypłukane z hałd usypanych podczas badań prowadzonych przed 1949 rokiem przez L. Sawickiego i później przez K. Kowalskiego (Kowalski 1951, s. 367). Materiały te nigdy nie zostały opracowane. Prawdopodobnie mamy tutaj do czynienia z inwentarzem analogicznym do tego z Jaskini Zegarowej Dolnej.

W pobliskiej, usytuowanej na gruntach wsi Strzegowa, Jaskini Jasnej Strzegowskiej (ryc. 6) również odkryto relikty środkowopaleolitycznych poziomów kulturowych. Namulisko głównej komory rozkopał niemal całkowicie L. Sawicki w latach 1947 i 1949, natomiast K. Cyrek w 1991 roku badał boczny korytarz jaskini, tzw. Lisie Jamy (Kowalski 1951, s. 369; Rybicka, Cyrek 1997, s. 5). Środkowopaleolityczne materiały źródłowe wystąpiły w gliniasto-piaszczystych warstwach badanych przez L. Sawickiego (1953, 


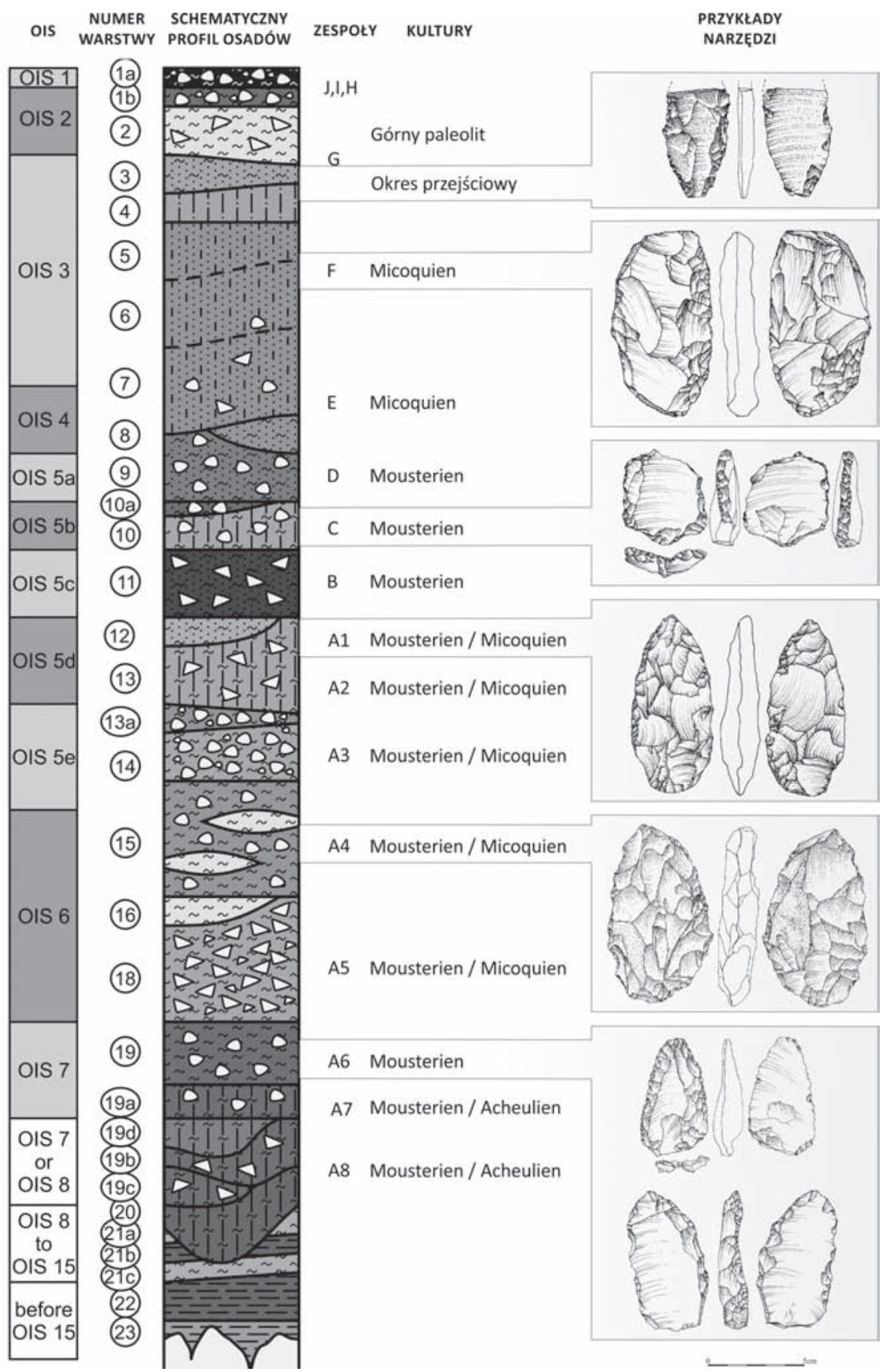

Ryc. 3. Schemat stratygrafii Jaskini Biśnik z przykładami środkowopaleolitycznych narzędzi z wybranych poziomów kulturowych (wg Sudoł i in. 2016)

Fig. 3. Stratigraphy scheme of Biśnik Cave with examples of Middle Paleolithic tools from selected cultural layers (after Sudoł et al. 2016) 


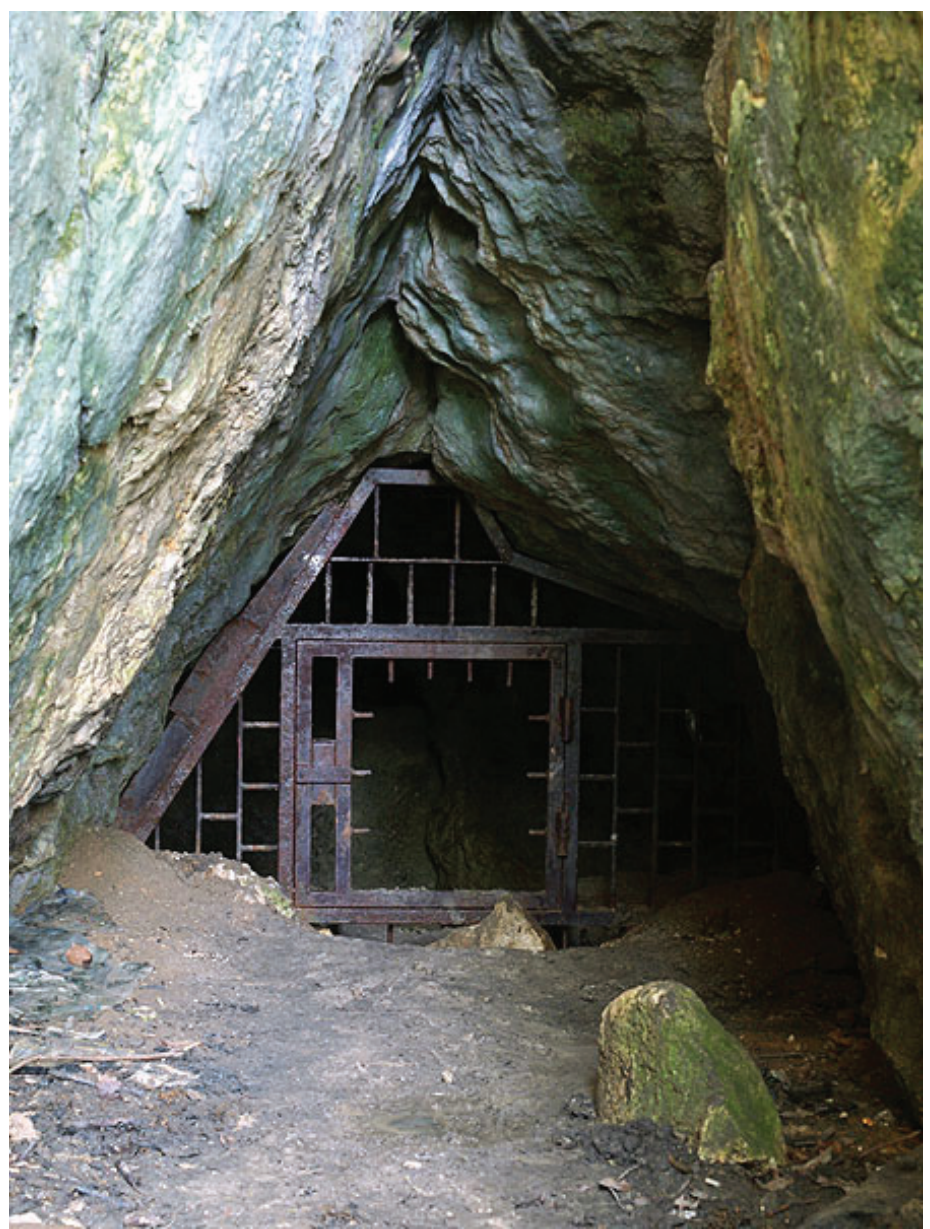

Ryc. 4. Jaskinia Zegarowa Dolna; widok na otwór wejściowy (fot. M. Sudoł)

Fig. 4. Zegarowa Dolna Cave; view of the entrance (photo M. Sudoł)

s. 176-179). Ten ubogi inwentarz dotychczas nie doczekał się opracowania i publikacji. Wśród archiwalnych materiałów zgromadzonych w Instytucie Archeologii i Etnologii PAN w Warszawie na szczególną uwagę zasługuje bifacjalny, mocno zredukowany nóż tylcowy (ryc. 7: 1), znaleziony w towarzystwie ostrza lewaluaskiego (ryc. 7: 2). Niewątpliwie wyroby te łączyć można z kulturą mikocką (Sudoł 2013). Do tego inwentarza bardzo dobrze nawiązuje środkowopaleolityczny, jednostronnie opracowany nóż (ryc. 7: 3), znaleziony na powierzchni pola ornego przed otworem wejściowych do jaskini przez Jadwigę i Lucjana Wodarzów w październiku 2013 roku na polu, około $20 \mathrm{~m}$ przed otworem jaskini. Przed podjęciem terenowych badań weryfikacyjnych trudno rozstrzygnąć o depozycyjnym charakterze tego znaleziska. 


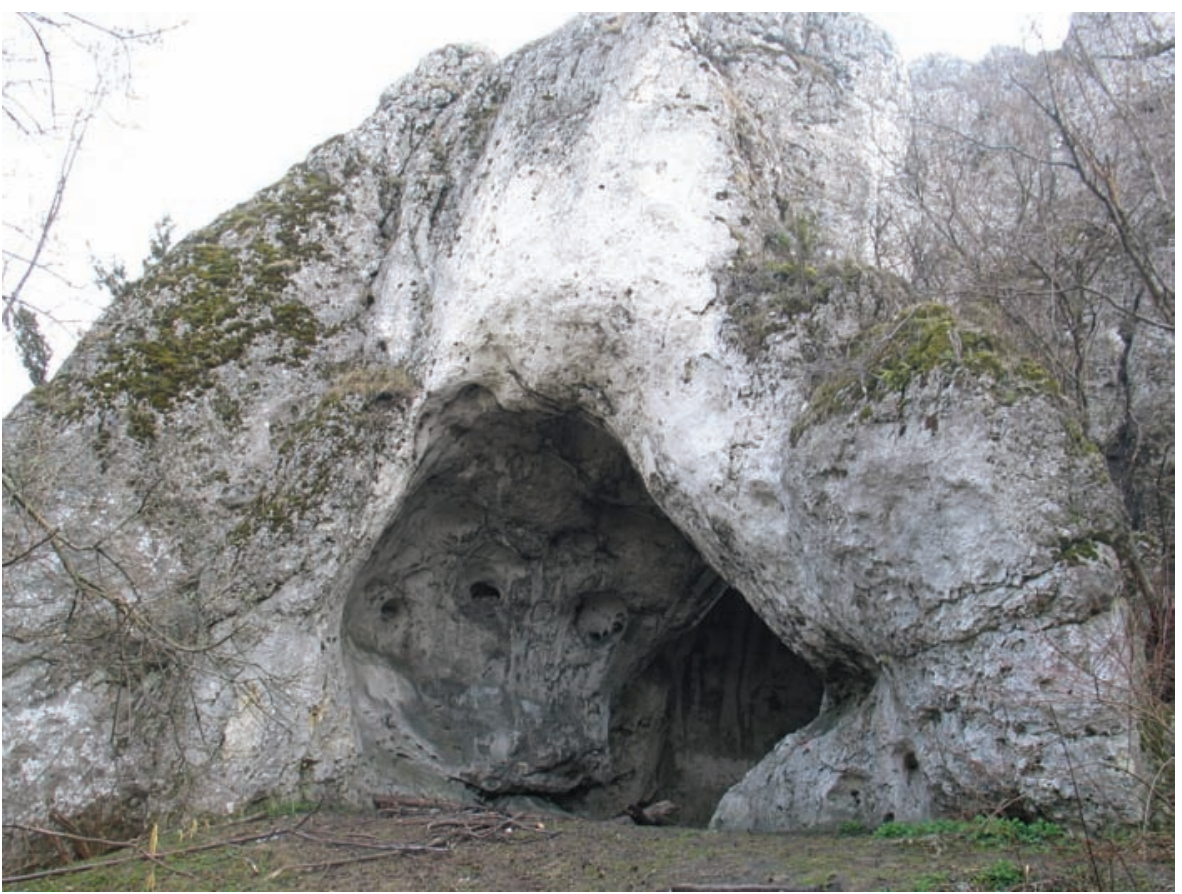

Ryc. 5. Jaskinia Jasna Smoleńska; widok skały z otworem wejściowym (fot. M. Sudoł) Fig. 5. Jasna Smoleńska Cave; view of the rock with the entrance (photo M. Sudoł)

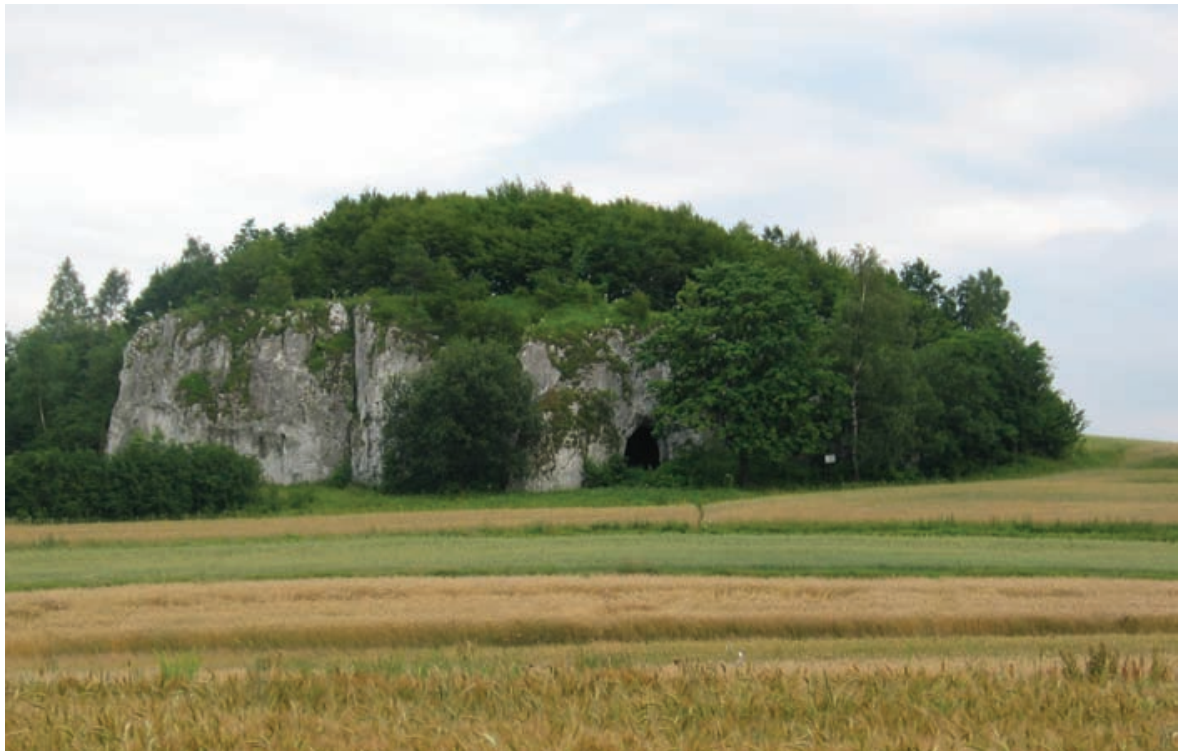

Ryc. 6. Jaskinia Jasna Strzegowska; widok ogólny (fot. M. Sudoł)

Fig. 6. Jasna Strzegowska Cave; general view (photo M. Sudoł) 

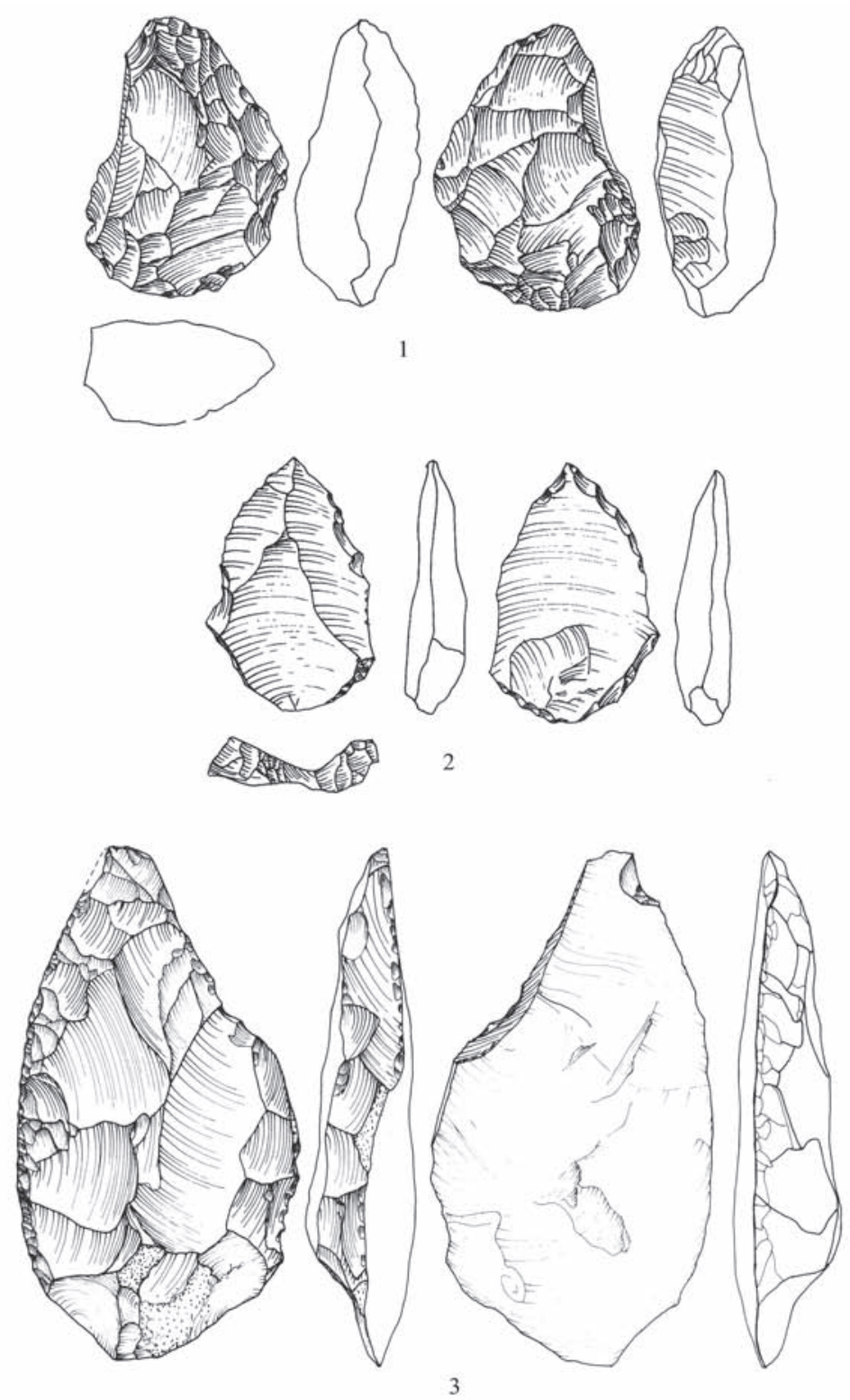

\section{0} $5 \mathrm{~cm}$

Ryc. 7. Jaskinia Jasna Styrzegowska. Wybór środkowopaleolitycznych wyrobów krzemiennych: 1 - szczątkowy nóż tylcowy; 2 - ostrze lewaluaskie; 3 - jednostronny nóż tylcowy (wg Sudoł i in. 2016)

Fig. 7. Jasna Strzegowska Cave. Selected examples of Middle Paleolithic flint artefacts: 1 - reduced backed knife; 2 - Levalloisian point; 3 - unifacially-worked knife (after Sudoł et al. 2016) 
W tym miejscu należy wspomnieć, że badania prowadzone w sąsiedniej dolinie Udorki, w nowoodkrytej Jaskini Perspektywicznej (ryc. 8) i sąsiednich schroniskach, także ujawniły relikty środkowopaleolitycznego poziomu zasiedlenia (Sudoł, Cyrek i in. 2013; Sudoł i in. w druku), jednak na obecnym etapie badań nie jest możliwe określenie jego przynależności kulturowej. W tej samej warstwie odkryto liczne kopalne szczątki fauny plejstoceńskiej, między innymi niedźwiedzia jaskiniowego, hieny jaskiniowej, renifera, nosorożca włochatego i jelenia olbrzymiego.

Relikty środkowopaleolitycznego osadnictwa znane są także z kilku stanowisk zlokalizowanych w północnej części Wyżyny Ryczowskiej. W Jaskini Deszczowej zadokumentowano sześć poziomów kulturowych, wśród nich zaś trzy środkowopaleolityczne (ryc. 9). Najbardziej charakterystyczne i najliczniejsze są wyroby z warstwy V; na szczególną uwagę zasługuje nóż z dwustronnie opracowanym ostrzem (ryc. 10: 1) oraz zgrzebło podłużne wypukłe typu Quina (ryc. 10: 2). Ponadto w inwentarzu czytelna jest technika lewaluaska manifestowana obecnością wióra i odłupków lewaluaskich (ryc. 10: 3, 5), a także inna odłupkowa, co poświadczają dwa rdzenie odłupkowe ze zmienioną orientacją (ryc. 10: 7) i niecharakterystyczne odłupki (Cyrek 2009). Obecność narzędzia w typie noża i techniki lewaluaskiej sugerują mikocką proweniencję kulturową 5 poziomu kulturowego z Jaskini Deszczowej. Niestety, dwa pozostałe poziomy środkowopaleolityczne (4 i 6), są mało charakterystyczne. Czas sedymentacji warstw VI-IV określony został na wczesny Vistulian, co potwierdza analiza faunistyczna (Cyrek i in. 2000).

Pojedyncze, również niecharakterystyczne artefakty o środkowopaleolitycznym charakterze zostały znalezione w Jaskini Złodziejskiej (ryc. 11) oraz w Schronisku na Górze Słupsko (ryc. 12) (Cyrek 2009).

Podobnie datowane - na okres zlodowacenia Wisły i interglacjał eemski - są materiały archeologiczne odkryte w Jaskini Dziadowa Skała (ryc. 13). Niestety, środkowopaleolityczny materiał krzemienny jest niezwykle ubogi i mało charakterystyczny, przez co trudno odnieść go precyzyjnie do konkretnej jednostki kulturowej. Składają się na niego pojedyncze odłupki krzemienne oraz okruchy termiczne zapewne z wtórną obróbką (ryc. 14: 2-5). W tym samym poziomie odkryto kości zwierzęce ze śladami działalności człowieka, z których najciekawsze jest żebro z intencjonalnymi nacięciami (ryc. 14: 1) (Chmielewski 1958, s. 34). Ponadto znaleziono żuchwę i szczękę konia z pojedynczymi zębami, zdeponowane w obiekcie otoczonym płytami i gruzem wapiennym, a także w bliskim sąsiedztwie kość krzyżową konia oraz fragment miednicy i kość ramieniową nosorożca (Chmielewski 1958, s. 36-37). Waldemar Chmielewski, na podstawie korelacji utworów oraz cha- 


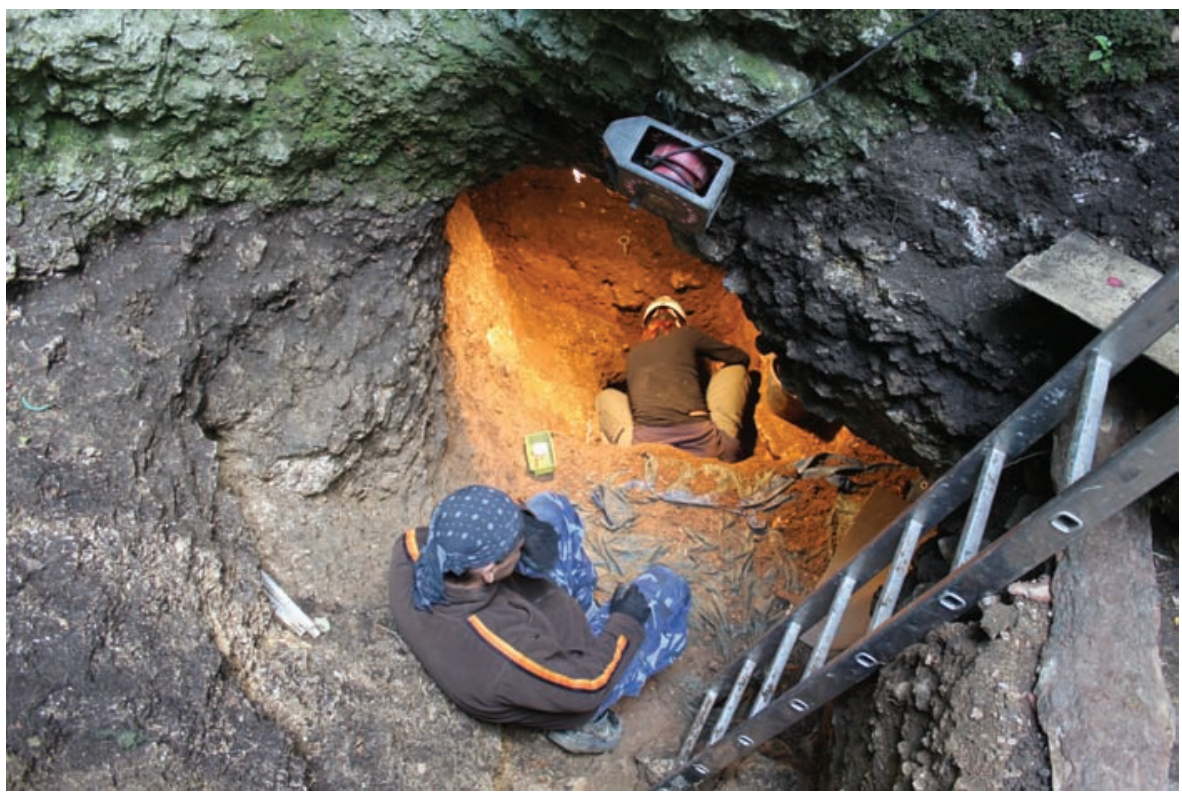

Ryc. 8. Jaskinia Perspektywiczna; widok na otwór wejściowy boczny (badania w 2013 roku) (fot. M. Sudoł)

Fig. 8. Perspektywiczna Cave; view of the side entrance (research from 2013) (photo M. Sudoł)

Ryc. 9. Jaskinia Deszczowa; widok ogólny (fot. M. Sudoł)

Fig. 9. Deszczowa Cave; general view (photo M. Sudoł)

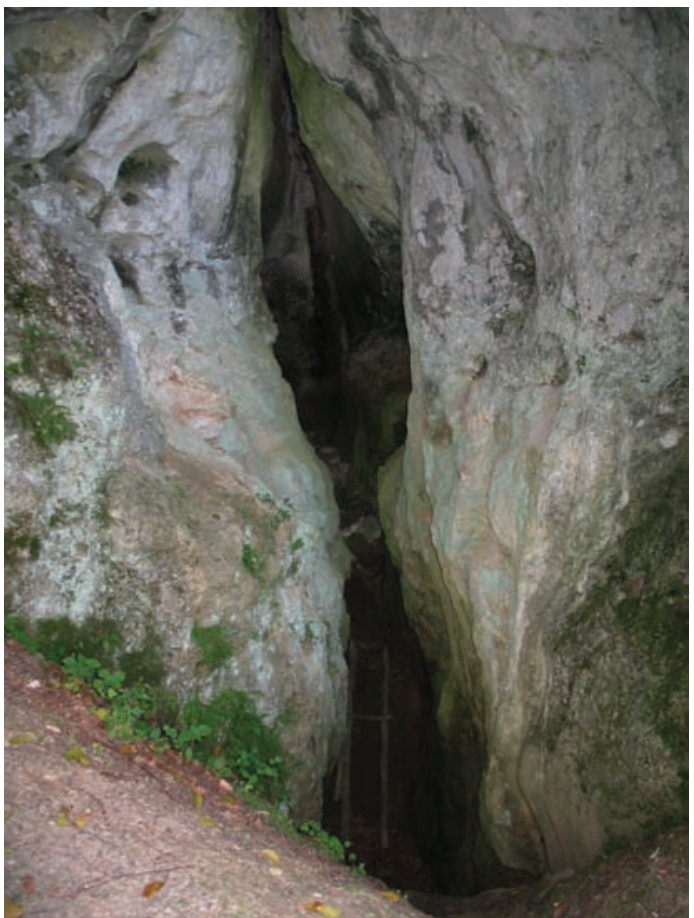



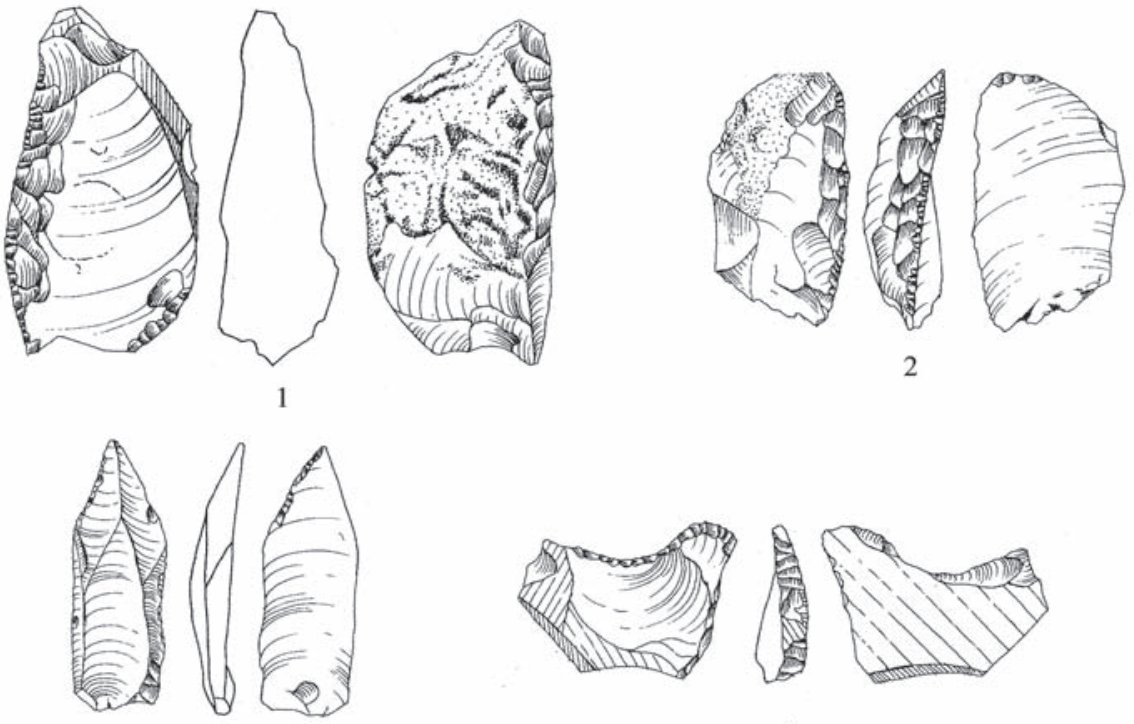

4

3
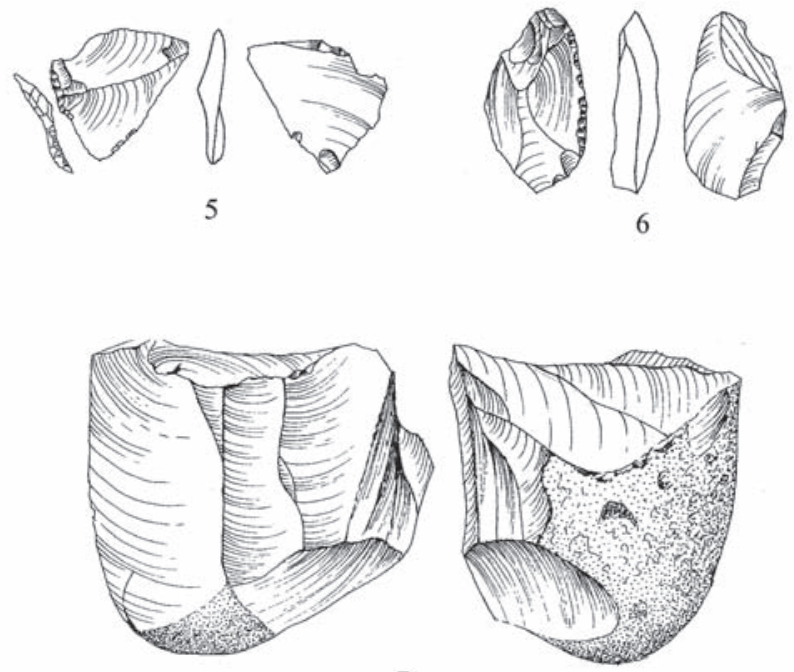

7

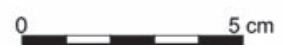

Ryc. 10. Jaskinia Deszczowa. Przykłady środkowopaleolitycznych wyrobów krzemiennych: 1 - nóż z częściowo dwustronną obróbką; 2 - zgrzebło; 3 - wiór lewaluaski; 4 - narzędzie wnękowe; 5 - pseudo-ostrze lewaluaskie; 6 - odłupek retuszowany; 7 - rdzeń odłupkowy ze zmienioną orientacją (wg Cyrek i in. 2000)

Fig. 10. Deszczowa Cave. Examples of Middle Palaeolithic flint artefacts: 1 - bifacial knife; 2 - side-scraper; 3 - Levallois blade; 4 - notched tool; 5 - pseudo-Levallois point; 6 - retouched flake; 7 - flake core with altered orientation (after Cyrek et al. 2000) 


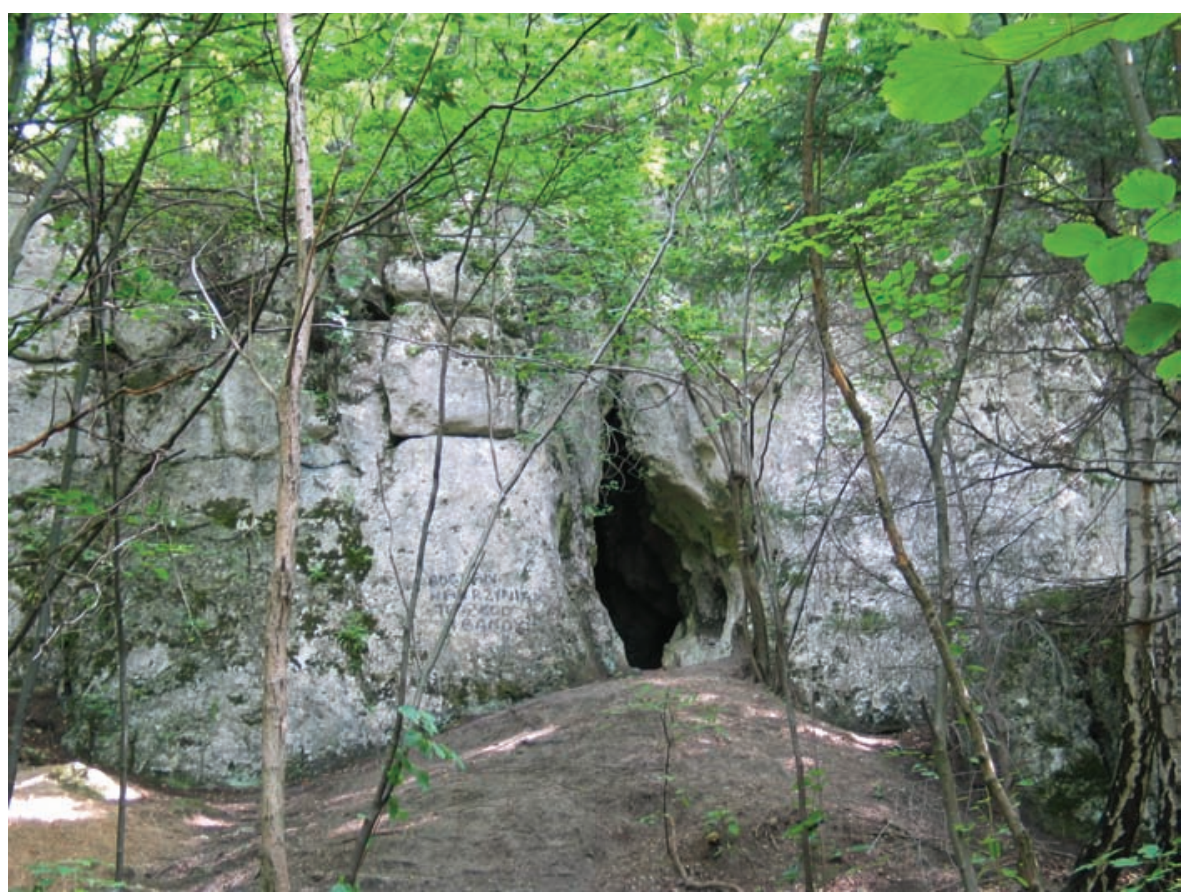

Ryc. 11. Jaskinia Złodziejska; widok ogólny (fot. M. Sudoł)

Fig. 11. Złodziejska Cave; general view (photo M. Sudoł)

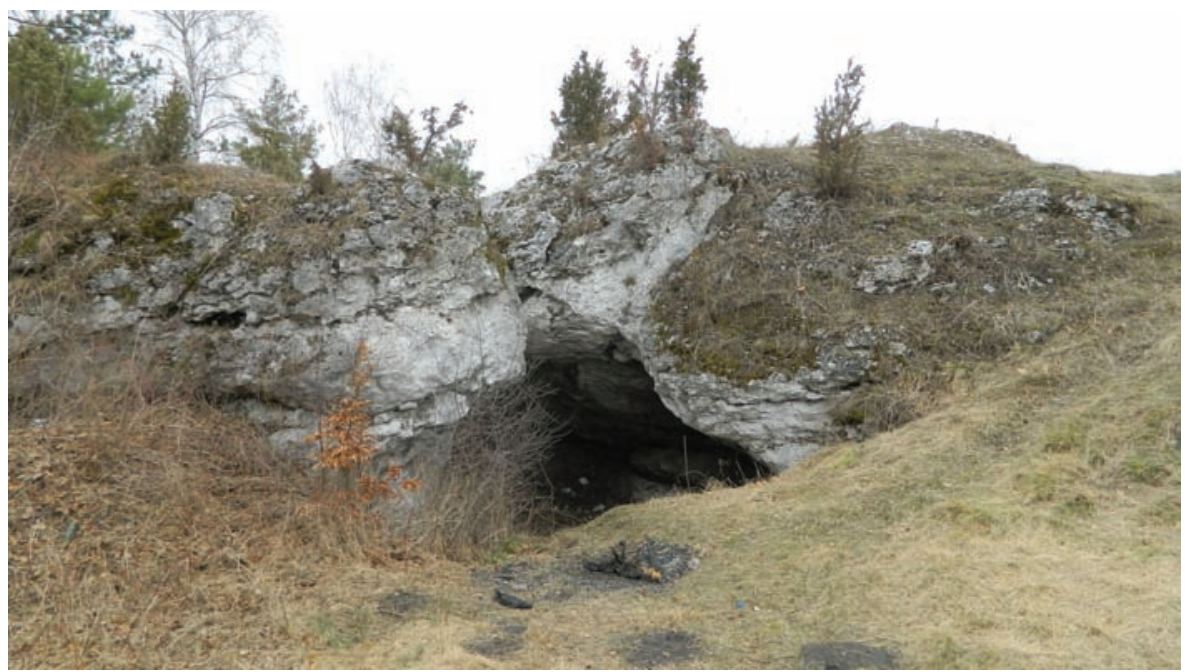

Ryc. 12. Schronisko na Górze Słupsko; widok ogólny (fot. M. Sudoł)

Fig. 12. Shelter in Mt. Słupsko; general view (photo M. Sudoł) 


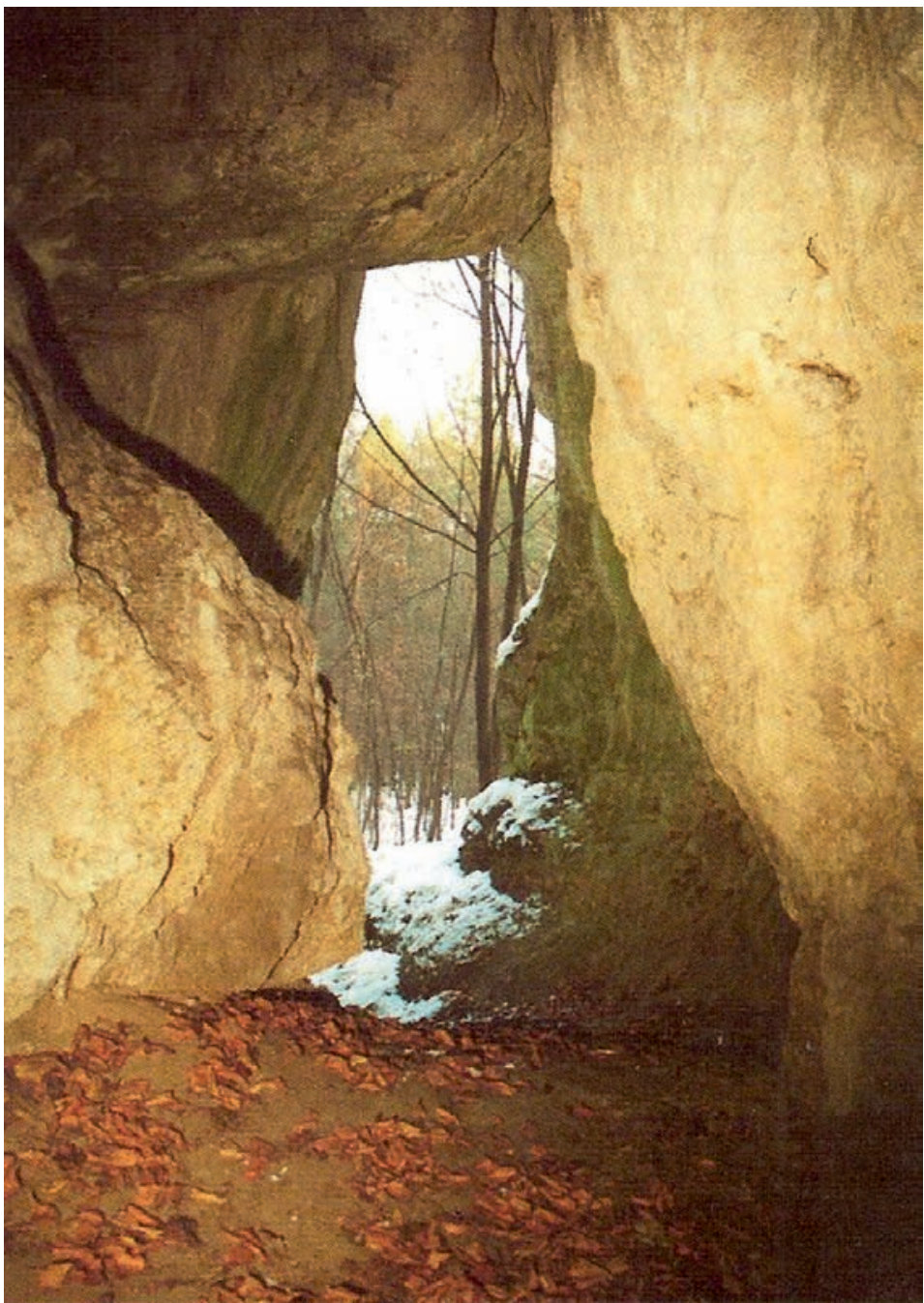

Ryc. 13. Jaskinia Dziadowa Skała; widok z wnętrza jaskini (wg Stefaniak i in. 2009)

Fig. 13. Dziadowa Skała Cave; view from the cave interior (after Stefaniak et al. 2009)

rakteru niezbyt charakterystycznych zabytków krzemiennych z Dziadowej Skały, zwrócił uwagę na różny charakter użytkowania sąsiadujących stanowisk jaskiniowych z tego samego okresu. Zdaniem tego badacza Dziadowa Skała jest przykładem obozowiska w bezpośrednim sąsiedztwie terenu łowów lub miejscem czasowego pobytu człowieka neandertalskiego, natomiast Jaskinia Okiennik z bogatymi, środkowopaleolitycznymi poziomami kulturowymi to stanowisko ze śladami dłuższego zasiedlenia (Chmielewski 1958, s. $46 ; 1967 ; 1975)$. 


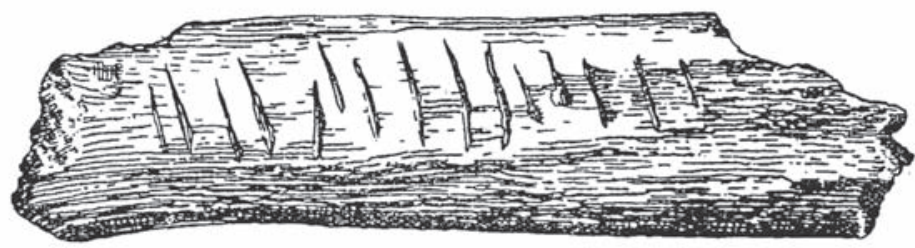

1
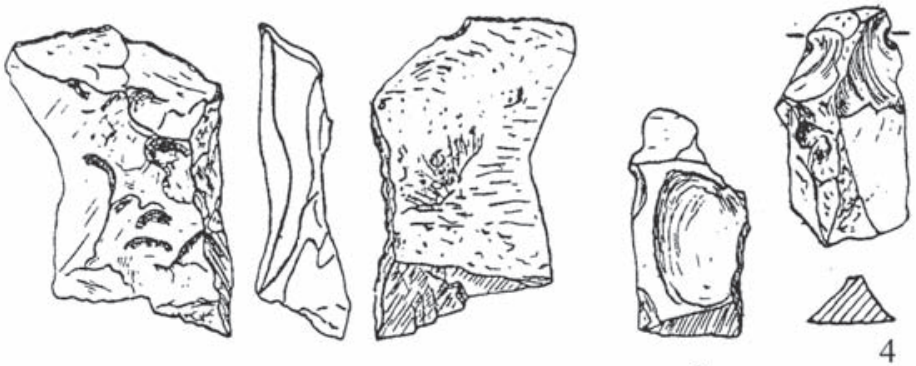

2

3
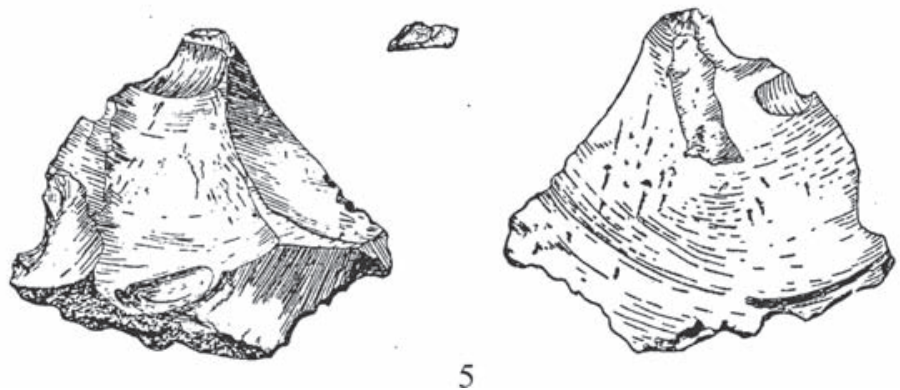

Ryc. 14. Jaskini Dziadowa Skała. Wybór środkowopaleolitycznych artefaktów: 1 - fragment żebra z nacięciami; 2, 5 - odłupki; 3, 4-odpadki termiczne wtórnie retuszowane (wg Chmielewski 1958)

Fig. 14. Dziadowa Skała Cave. Examples of Middle Palaeolithic flint artefacts: 1 - ribs with cuts; 2, 5-flakes; 3, 4-thermal chunks, secondarily retouched (after Chmielewski 1958)

Okres przejściowy i początek paleolitu górnego

W południowo-wschodniej części Wyżyny Ryczowskiej odnotowano ślady pobytu człowieka, które można łączyć z okresem przejściowym pomiędzy paleolitem środkowym a górnym, tzn. z kompleksem kultur z ostrzami liściowatymi. Takie stanowiska na terenie Polski należą do bardzo rzadkich.

Z przemieszanych osadów Jaskini Biśnik pochodzi fragment zespołu identyfikowanego z kulturą jerzmanowicką lub szelecką (Jaskinia Biśnik 2002; 
Sudoł 2013). Wśród form narzędziowych wyróżniają się wióry retuszowane, drapacz z masywnego, skróconego wióra z załuskanymi bokami (ryc. 15: 1) oraz rylce: łamaniec i węgłowy (ryc. 15: 2, 3). Zwraca też uwagę uszkodzone narzędzie w typie ostrza liściowatego, wykonane na wiórze opracowanym całkowicie na górnej płaszczyźnie retuszem powierzchniowym, częściowo płaskim i półstromym, stopniowym, przy krawędzi drobnym, lekko zębatym (ryc. 15: 4). Prawdopodobnie z tym inwentarzem należy łączyć nóż z najmłodszego inwentarza środkowopaleolitycznego, który mógł ulec redepozycji (ryc. 15: 5). Został on wykonany najprawdopodobniej z symetrycznego ostrza, a jego asymetria powstała na skutek wykorzystania uszkodzenia części wierzchołkowej narzędzia, które opracowano wtórnym retuszem zatępiającym. Zarówno ostrze, jak i wspomniany nóż zostały odkryte w najmłodszym zespole środkowopaleolitycznym (zespół F) (Jaskinia Biśnik 2002). Przynależność tych wyrobów do jednej z kultur z początku górnego paleolitu zdaje się potwierdzać data radiowęglowa z kości zwierzęcej, znalezionej w kontekście opisywanych narzędzi (Sudoł i in. w druku). Najprawdopodobniej mamy do czynienia ze zmieszaniem elementów młodszego inwentarza górnopaleolitycznego lub przejściowego ze starszym środkowopaleolitycznym.

W tej sytuacji interesujące jest znalezisko ostrza liściowatego, wykonanego w środkowopaleolitycznej technice (ryc. 16: 1), które zostało odkryte w położonym około $600 \mathrm{~m}$ od Jaskini Biśnik, Schronisku nad Jaskinią Zegar w Skałach Zegarowych (ryc. 17) (Krajcarz, Sudoł i in. 2012b). Niestety zostało ono znalezione na stoku przed jaskinią, natomiast badania przeprowadzone w samym schronisku wykazały obecność poziomu kulturowego z reliktami palenisk oraz kością ze śladami intencjonalnych nacięć (ryc. 16: 2), ale nie dostarczyły wyrobów krzemiennych. Data radiowęglowa z kości renifera pochodzącej z tego poziomu, nawiązuje do wcześniej opisywanego poziomu z jaskini Biśnik (Krajcarz, Sudoł i in. 2012b).

Opisane wyżej znaleziska z jaskini Biśnik oraz Schroniska nad Jaskinią Zegar są prawdopodobnie śladem zachodzących na tym obszarze zmian kulturowych w okresie 34-30 tys. lat BP.

\section{Górny paleolit}

Na najstarsze górnopaleolityczne wyroby natrafiono w środkowej części Wyżyny Ryczowskiej, w Schronisku IV w Górze Birów koło Podzamcza (ryc. 18) (Cyrek 2009), a także w części północnej Wyżyny, w Jaskini Deszczowej (Cyrek i in. 2000). 

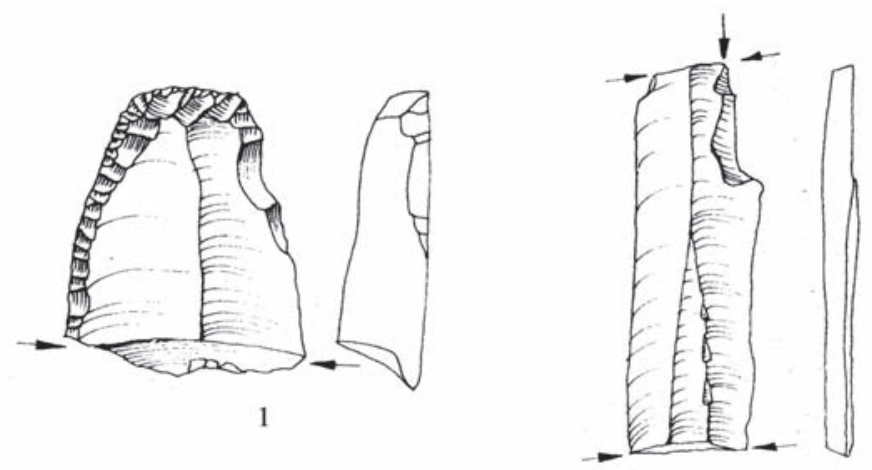

2

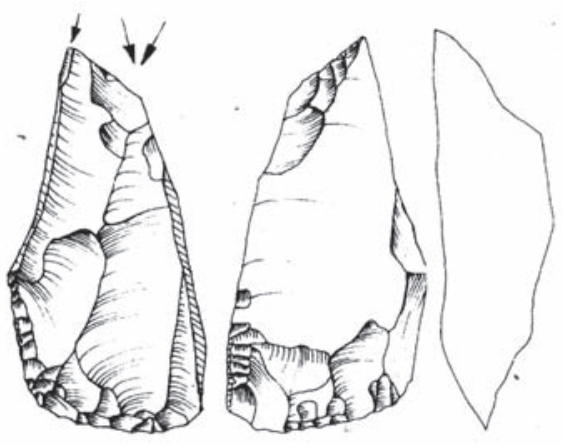

3

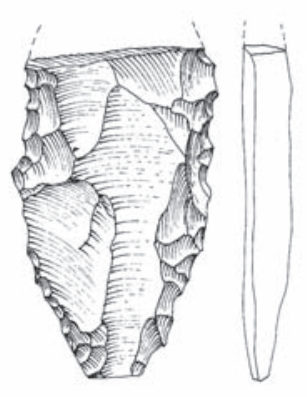

4

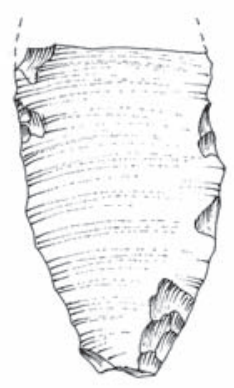

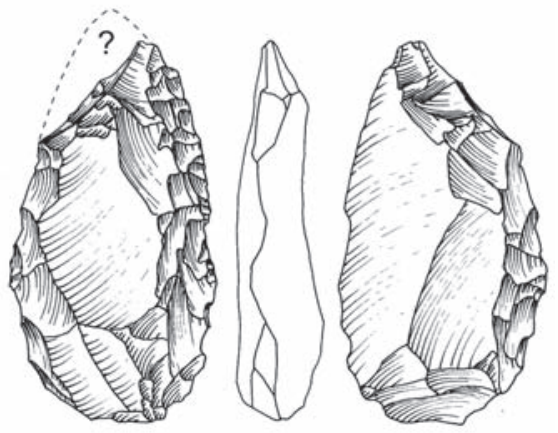

5 $5 \mathrm{~cm}$

Ryc. 15. Jaskinia Biśnik. Wybór narzędzi z warstw przejściowych i górnopaleolitycznych: 1 - drapacz; 2, 3 - rylce; 4 - fragment ostrza liściowatego; 5 - nóż (wg Sudoł i in. 2016)

Fig. 15. Biśnik Cave. Examples of tools from the transitional and Upper Palaeolithic levels: 1 - end-scraper; 2, 3 - burins; 4 - fragment of leaf-shaped point; 5 - knife (after Sudoł et al. 2016) 

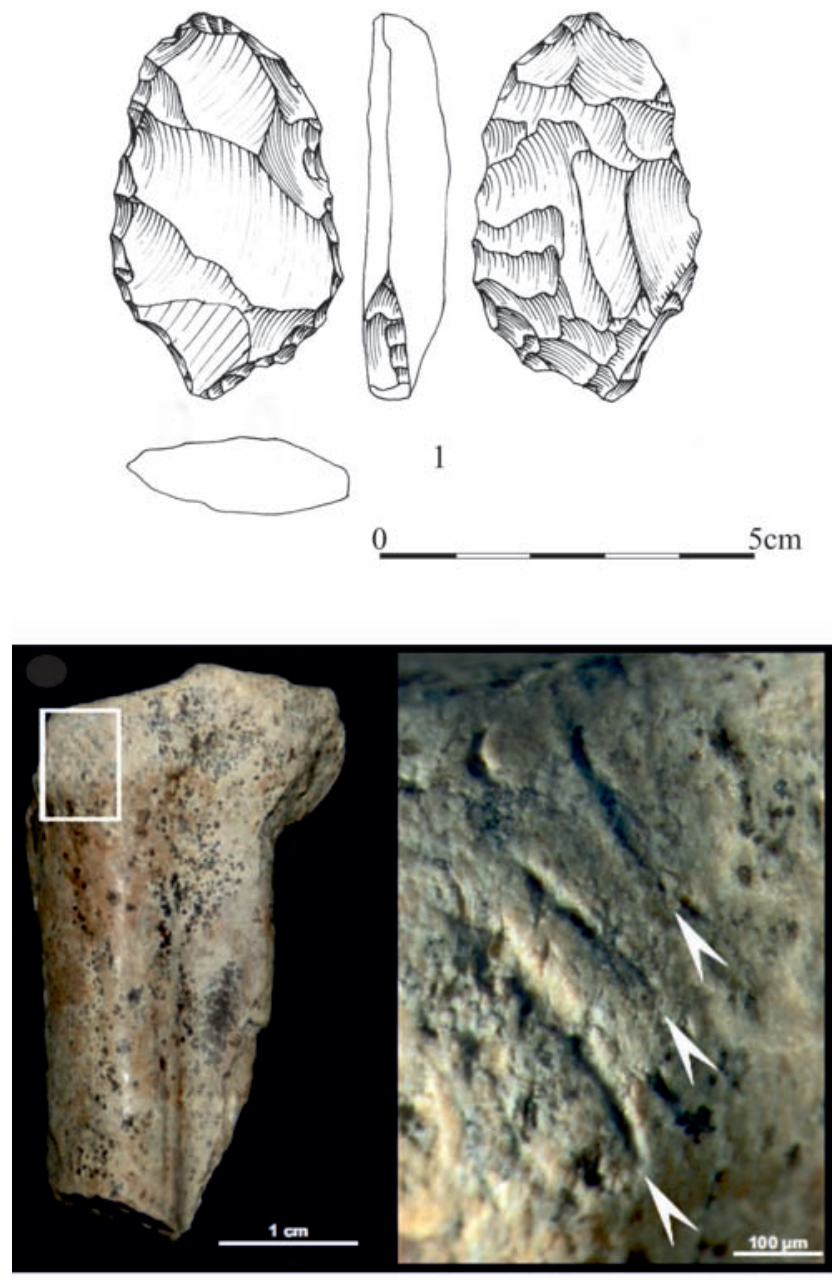

2

Ryc. 16. Schroniska nad Jaskinią Zegar. Wybór znalezisk: 1 - ostrze liściowate; 2 - kość zwierzęca (cervid metatarsal) z nacięciami (wg Sudoł i in. 2016)

Fig. 16. Shelter above the Zegar Cave. Examples of finds: 1 - leaf-shaped point; 2 - animal bone (cervid metatarsal) with cut mark (after Sudoł et al. 2016)

Oba zespoły charakteryzują się obecnością przedmiotów kościanych, noszących cechy kultury oryniackiej. Cechą charakterystyczną inwentarza z Jaskini Deszczowej są narzędzia krzemienne w typie rylców kombinowanych z wiórowcami (ryc. 19: 1, 3), rylce (ryc. 19: 2), drapacze kombinowane z wiórowcami (ryc. 19: 4), drapacze (ryc. 19: 5) oraz wiórowce (ryc. 19: 6) (Cyrek i in. 2000). Zespół uzupełniają wyroby z kości i poroża, przede wszystkim ornamentowana igła kościana (ryc. 20: 1) oraz fragment poroża 
Ryc. 17. Schronisko nad Jaskinią Zegar; otwór wejściowy (fot. M. Sudoł)

Fig. 17. Shelter above the Zegar Cave; entrance (photo M. Sudoł)
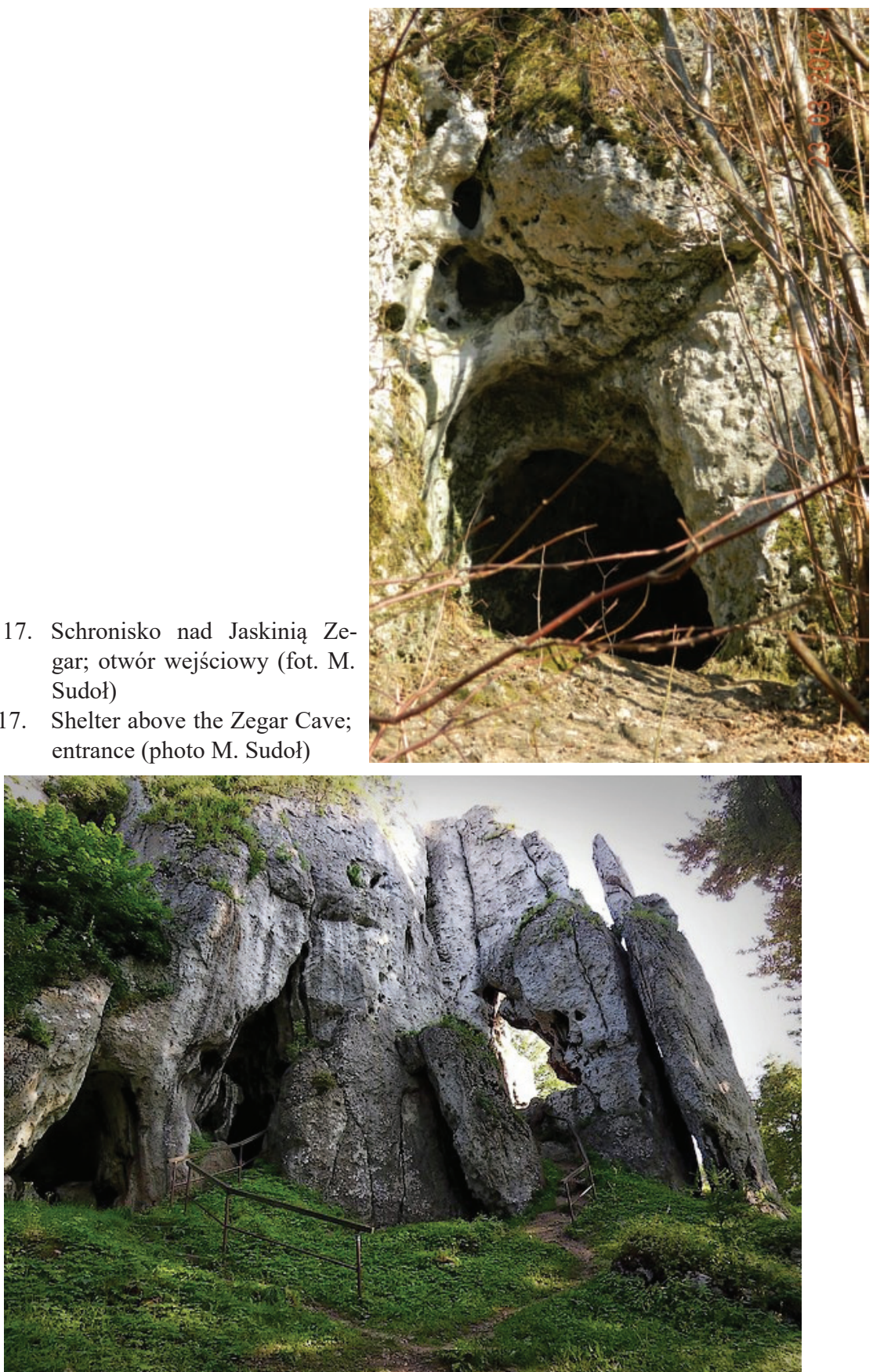

Ryc. 18. Schronisko IV Północne w Górze Birów koło Podzamcza; widok ogólny (fot. M. Sudoł)

Fig. 18. Shelter in Mt. Birów IV near Podzamcze; general view (photo M. Sudoł) 

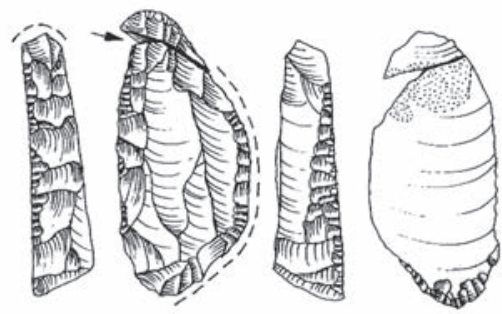

1
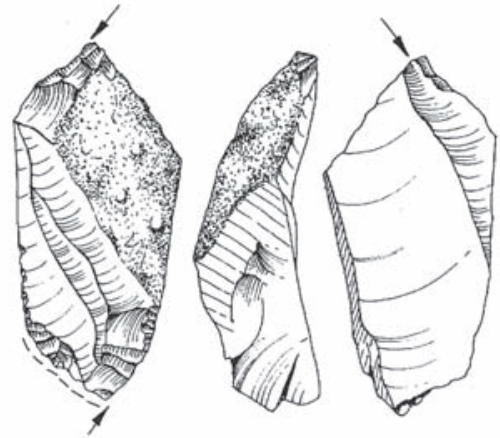

2

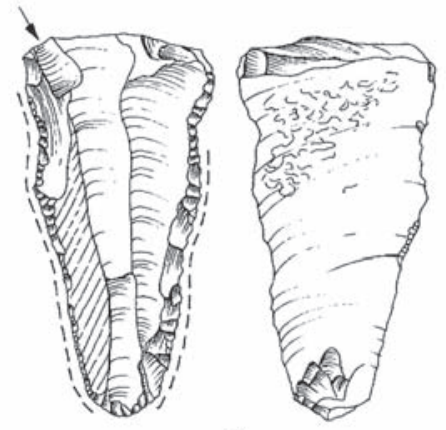

3
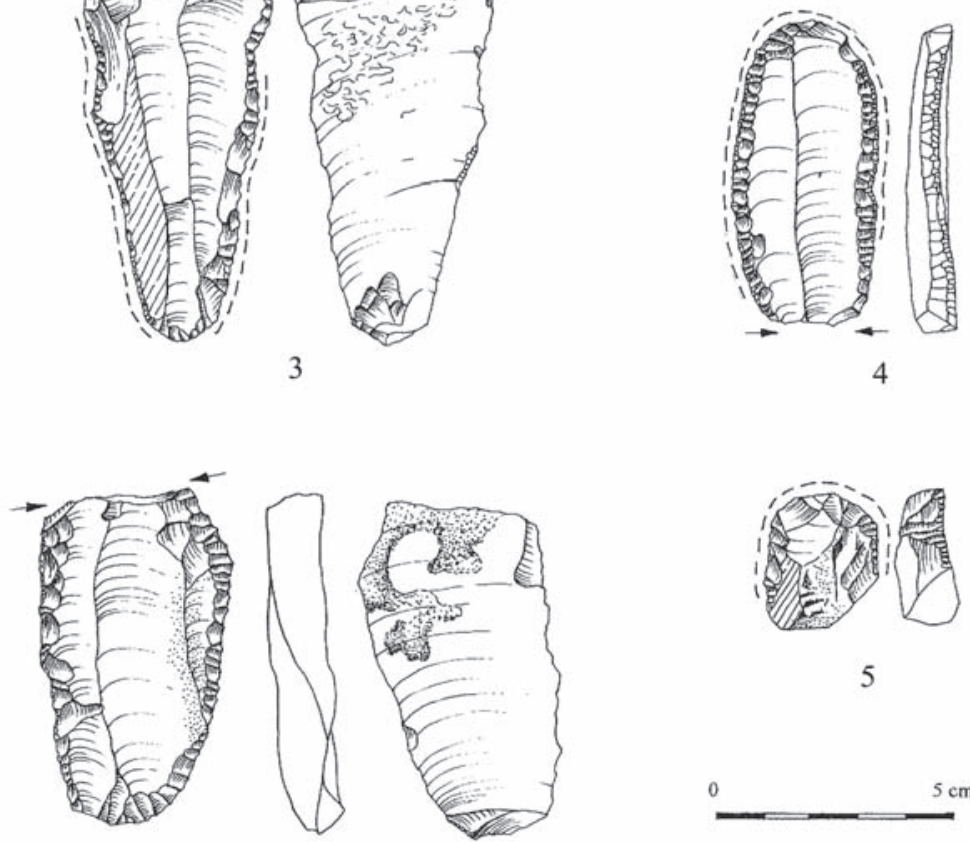

5

6

Ryc. 19. Jaskinia Deszczowa. Wybór wyrobów krzemiennych z oryniackiego poziomu kulturowego: 1,3 - rylce kombinowane $\mathrm{z}$ wiórowcami; 2 - rylec; 4 - rylec kombinowany z drapaczem; 5 - drapacz; 6 - wiórowiec (wg Cyrek i in. 2000)

Fig. 19. Deszczowa Cave. Examples of flint artefacts from aurignacian cultural level: 1, 3 - burins combined with edge retouched blades; 2 - burin; 4 - burin combined with a end-scraper; 5 - end-scraper; 6 - edges retouched blade (after Cyrek et al. 2000) 
pokryty płytkim reliefem (ryc. 20: 2) i dwustronnie ucięty fragment ptasiej kości (ryc. 20: 3). Z oryniackim poziomem łączone jest także żebro nosorożca włochatego z nacięciami (ryc. 20: 4) (Cyrek i in. 2000; Cyrek 2002). Do tych znalezisk dobrze nawiązuje fragment poroża zdobionego ornamentem punktowym ze Schroniska IV Północnego na Górze Birów (ryc. 20: 5) (Cyrek 2009).

Ślady penetracji południowej części Wyżyny Ryczowskiej w górnym paleolicie zostały rozpoznane w Jaskini Perspektywicznej, w dolinie Udorki (Sudoł, Cyrek i in. 2013; Sudoł, Krajcarz, Krajcarz 2013). Poziom kulturowy zachował się tu jako warstwa o intensywnie ciemnym kolorze, wynikającym z obecności dużej ilości węgli drzewnych. W jego obrębie odkryto kilkadziesiąt wyrobów krzemiennych o charakterze pracowniano-podomowym. Wśród nich wyróżniają się narzędzia w postaci masywnych asymetrycznych przekłuwaczy (ryc. 21: 1, 3) i wiertników (ryc. 21: 2). Inwentarz uzupełniają wióry (ryc. 21: 4-6), w tym bardzo masywne (ryc. 22: 1, 2) oraz rdzenie wiórowe (ryc. 22: 3, 4). Niestety, na postawie tego nielicznego zbioru trudno dokonać wiarygodnej charakterystyki kulturowej, ponieważ podobne formy można spotkać w inwentarzach różnych kultur górnego i schyłkowego paleolitu. Sytuację komplikuje fakt, że inwentarz został odkryty w osadach stokowych, tuż przed otworem wejściowym do jaskini. Zachowane struktury sedymentacyjne i mieszany charakter fauny (ssaki leśne łącznie ze stepotundrowymi) wskazują, że nie można wykluczyć zmieszania kilku zespołów archeologicznych. Badania wykopaliskowe w Jaskini Perspektywicznej są kontynuowane i być może pozwolą wyjaśnić skomplikowaną sytuację stratygraficzną.

Młodsza faza zasiedlenia Wyżyny Ryczowskiej związana jest $\mathrm{z}$ horyzontem górnopaleolitycznym, odpowiadającym kulturze graweckiej lub epigraweckiej. Nieliczne znaleziska, takie jak ostrze graweckie (ryc. 23: 1), wiórki tylcowe (ryc. 23: 2, 3), drapacze (ryc. 23: 4), rylec (ryc. 23: 5) oraz trójkątny wyrób $\mathrm{z}$ wapienia (wisiorek?) z dwoma przewierconymi otworami (ryc. 23: 6), odkryto we wspomnianej wyżej Jaskini Jasnej Strzegowskiej (Rybicka, Cyrek 1997; Mirosław-Grabowska, Cyrek 2009). Być może z grawetienem można łączyć pojedyncze wyroby krzemienne i kościane ostrze(?) z najmłodszych poziomów Jaskini Biśnik (Jaskinia Biśnik 2002). Na inwentarze identyfikowane z kulturą epigrawecką natrafiono także w północnej części Wyżyny Ryczowskiej - w Jaskini Deszczowej (Cyrek i in. 2000), Jaskini Dziadowa Skała (Chmielewski 1958) oraz Schronisku Ruska Skała (Cyrek 2009). Wśród nich wyróżnia się inwentarz z Jaskini Deszczowej, zawierający między innymi wiórowce kombinowane z przekłuwaczami (ryc. 24: 1-3) oraz ostrza kościane (ryc. 24: 4, 5) (Cyrek i in. 2000). 


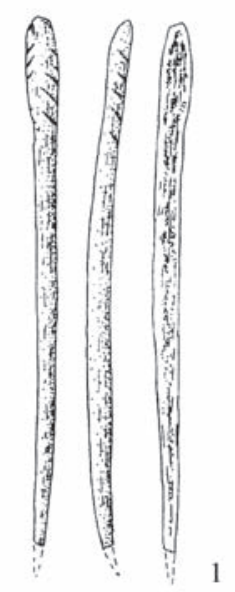

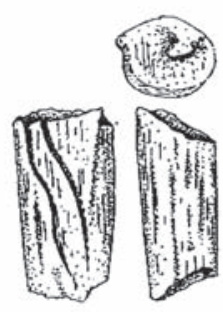

2

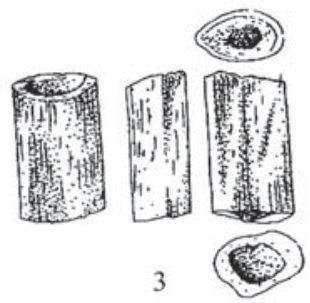

0 $5 \mathrm{~cm}$
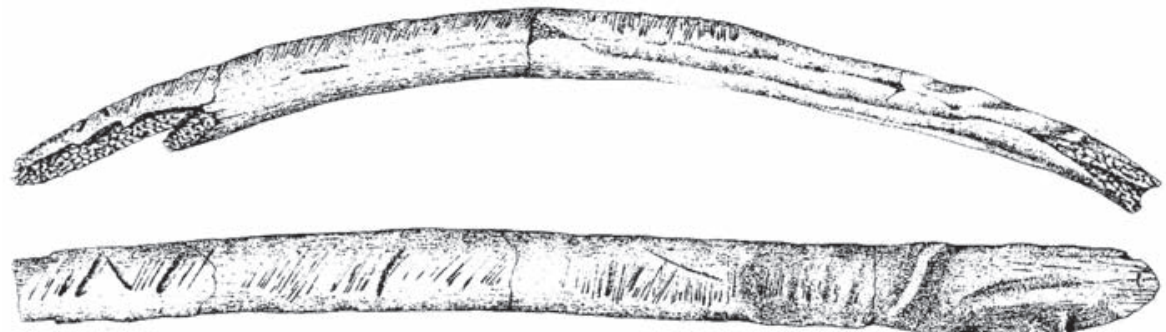

4

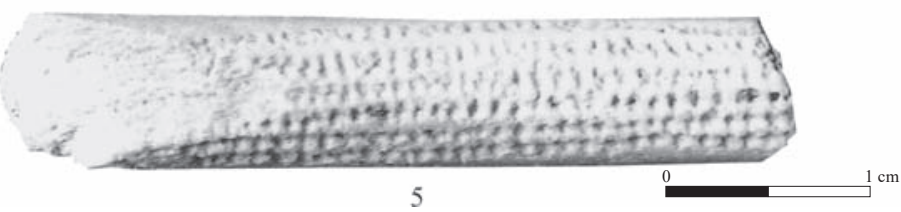

Ryc. 20. Wybór wyrobów kościanych kultury oryniackiej z Jaskini Deszczowej (1-4) oraz Schroniska IV Północnego w Górze Birów (5): 1 - ornamentowana igła kościana; 2 - fragment poroża z reliefem; 3 - fragment dwustronnie uciętej ptasiej kości; 4 - żebro nosorożca włochatego z nacięciami; 5 - ornamentowany fragment poroża (1-4 - wg Cyrek 2002; 5 - wg Cyrek 2009)

Fig. 20. Selection of bones artefacts of Aurignacian Culture from Deszczowa Cave (1-4) and Shelter in Mt. Birów IV (5): 1 - ornamented bone needle; 2 - fragment of antlers with relief; 3 - fragment of a bird bone cut on both sides; 4 - rib of a woolly rhinoceros with cuts ; 5 - ornamented fragment of antlers (1-4 - after Cyrek 2002; 5 - after Cyrek 2009) 

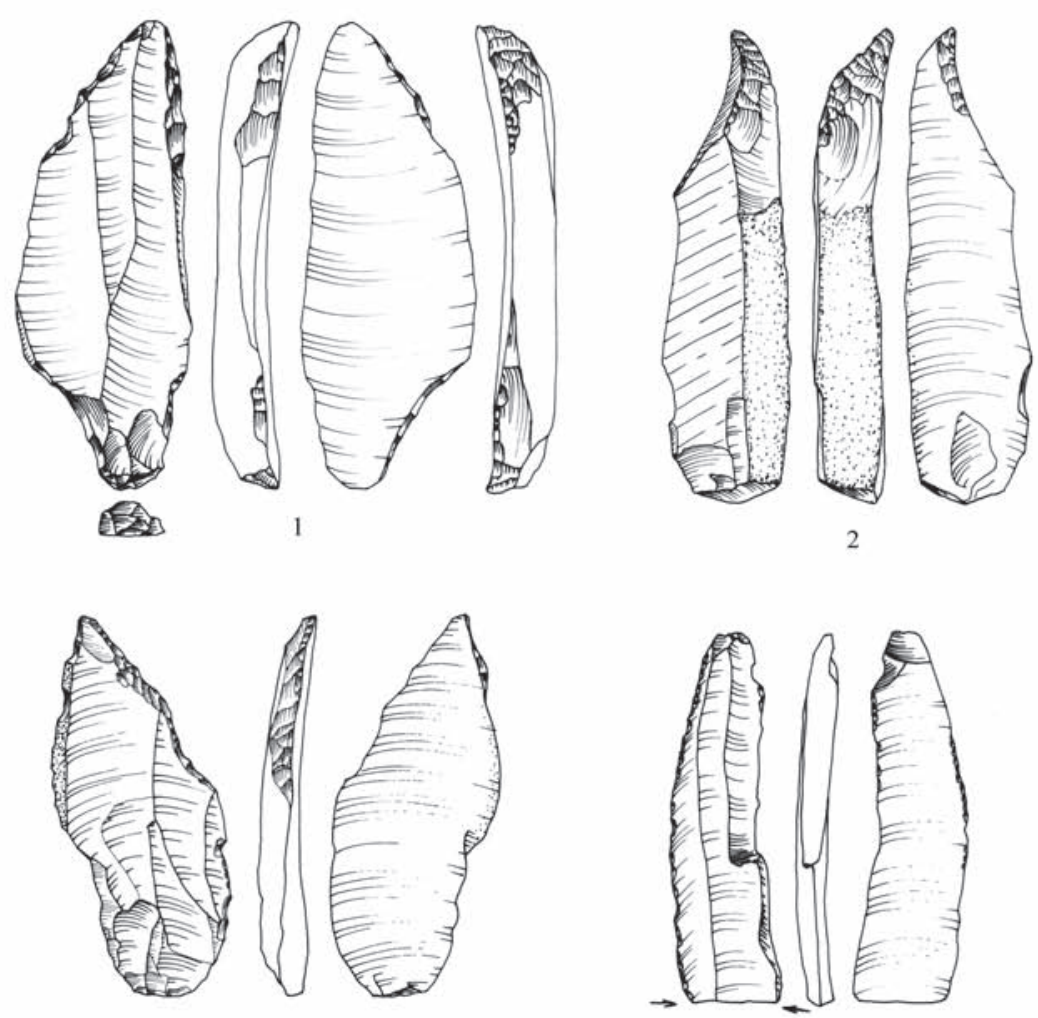

3

4
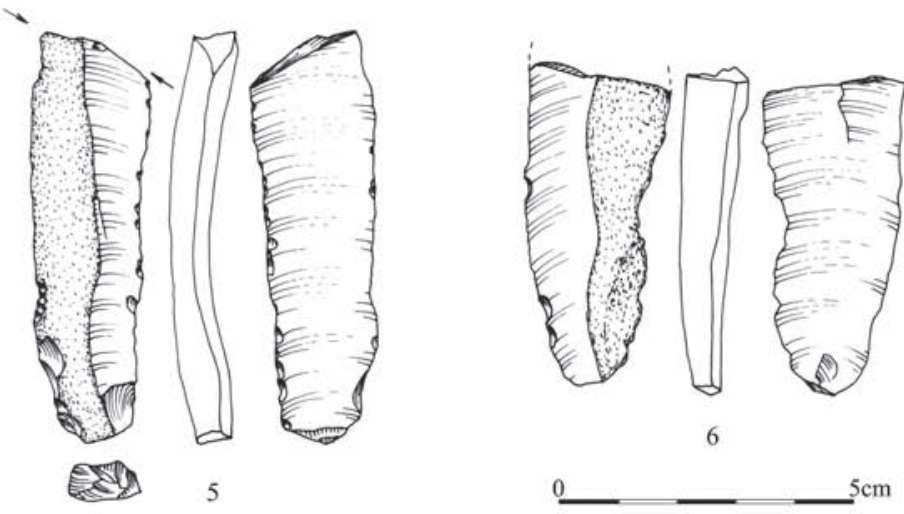

Ryc. 21. Jaskinia Perspektywiczna. Przykłady wyrobów krzemiennych z poziomów górnopaleolitycznych: 1, 3 - przekłuwacze; 2 - wiertnik; 4, 5 - fragmenty wiórów (wg Sudoł $\mathrm{i}$ in. 2016)

Fig. 21. Perspektywiczna Cave. Examples of flint artefacts from Upper Palaeolithic level: 1, 3 - perforators; 2 - borer; 4-6 - fragments of blades (after Sudoł et al. 2016) 

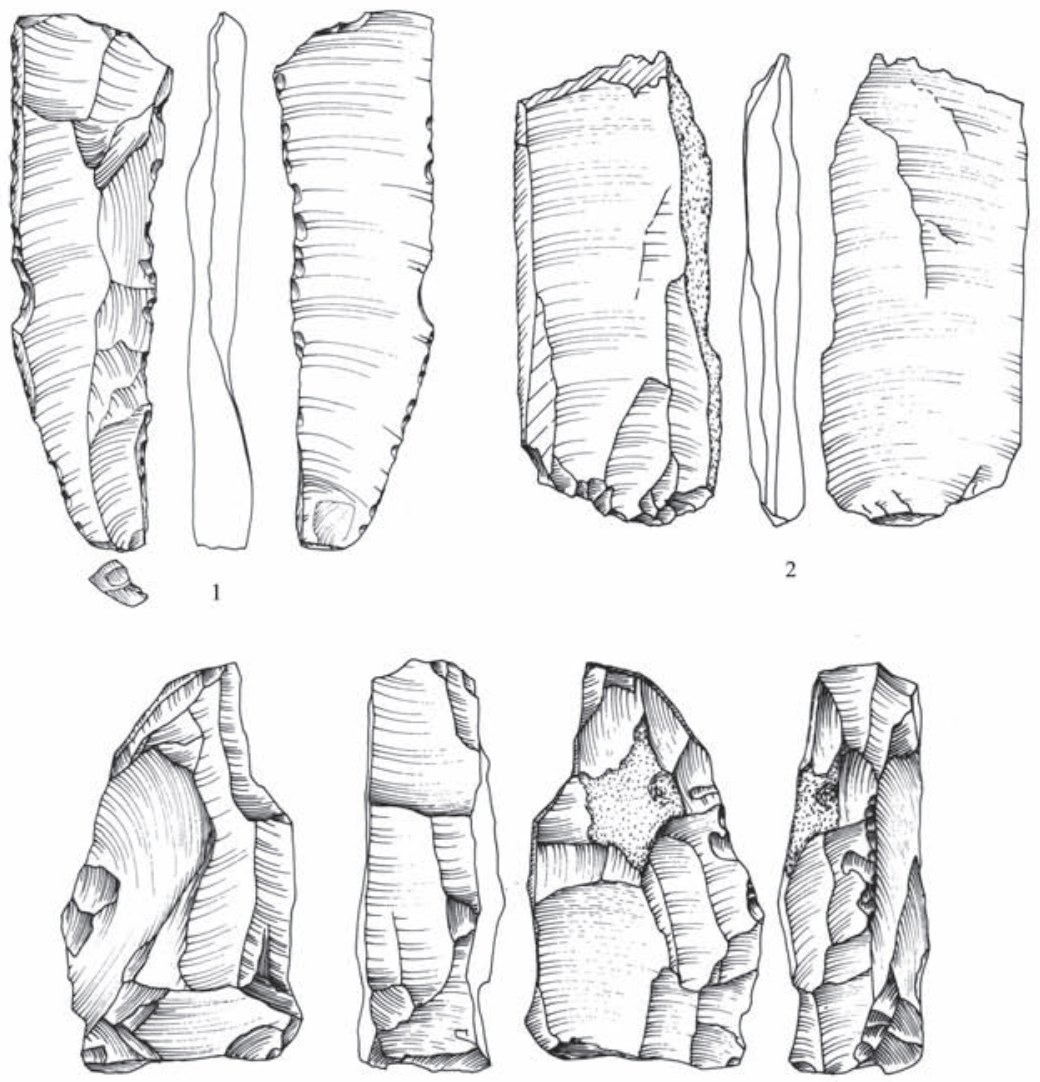

3
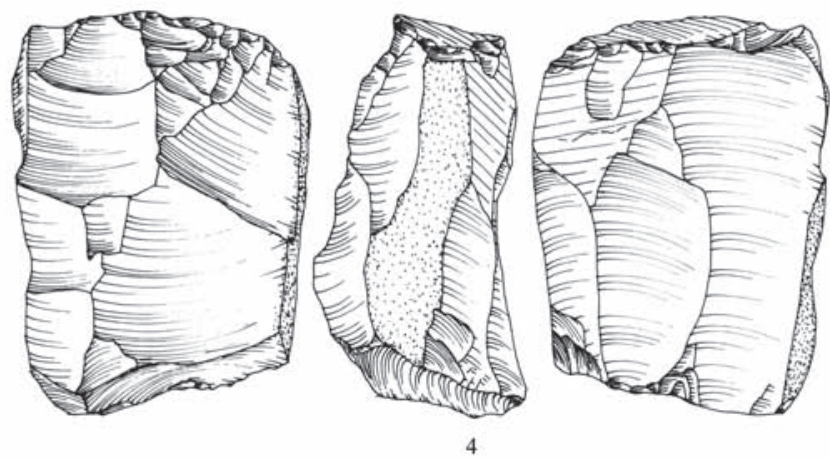
$5 \mathrm{~cm}$

Ryc. 22. Jaskinia Perspektywiczna. Przykłady wyrobów krzemiennych z poziomów górnopaleolitycznych: 1, 2 - masywne wióry; 3, 4-rdzenie (wg Sudoł i in. 2016)

Fig. 22. Perspektywiczna Cave. Examples of flint artefacts from Upper Palaeolithic level: 1, 2 - massive blades; 3, 4 - cores (after Sudoł et al. 2016) 


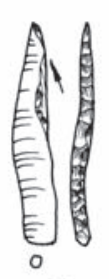

1

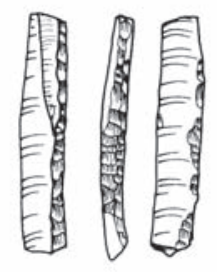

2

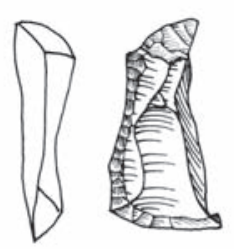

3
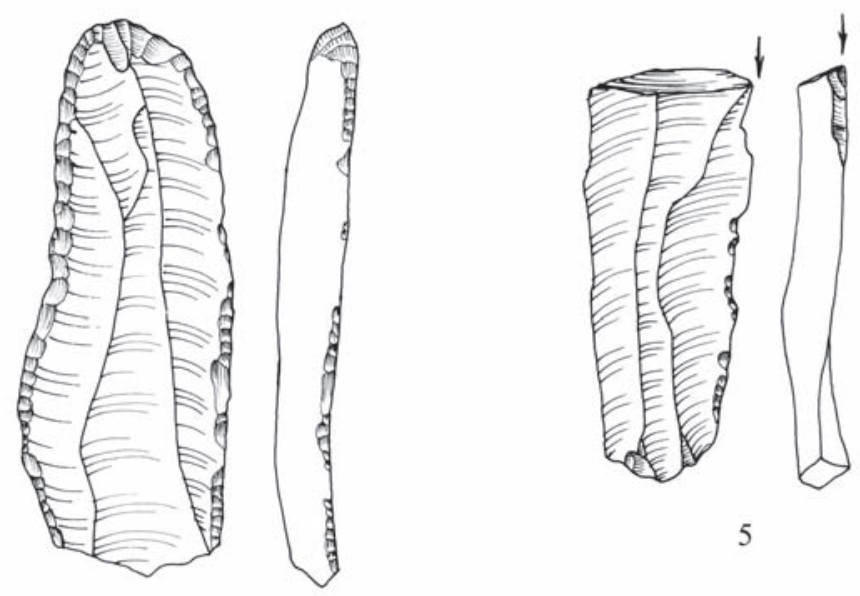

\section{0} $5 \mathrm{~cm}$
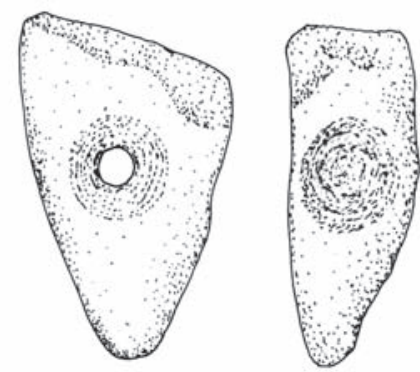

6

Ryc. 23. Jaskinia Jasna Strzegowska. Wybór wyrobów z epigraweckiego poziomu kulturowego: 1 - ostrze graweckie; 2, 3 - wiórki tylcowe; 4 - drapacz; 5 -rylec; 6 - przedmiot z wapienia z przewierconym dwustronnie otworem (wg Mirosław-Grabowska, Cyrek 2009, ze zmianami)

Fig. 23. Jasna Strzegowska Cave. Examples of arefacts from epigravettian cultural level: 1 - Gravettian point; 2, 3 - backed microblades; 4 - end-scrapers; 5 - burin; 6 - triangular limestone pendant with two bored orifices (after Mirosław-Grabowska, Cyrek 2009, with changes) 


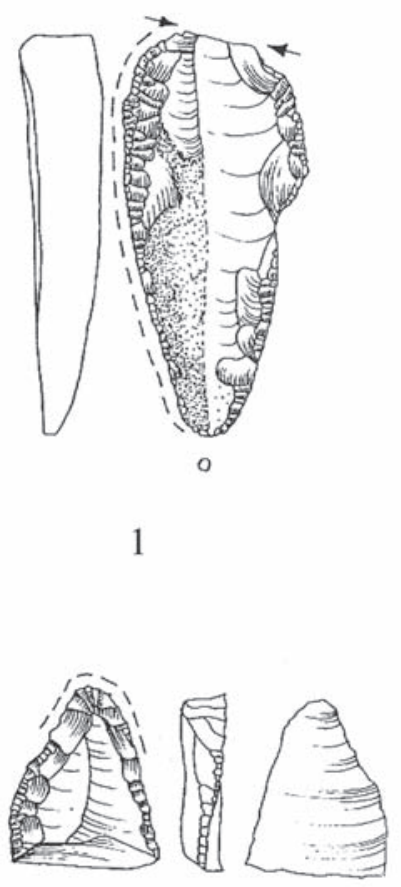

3
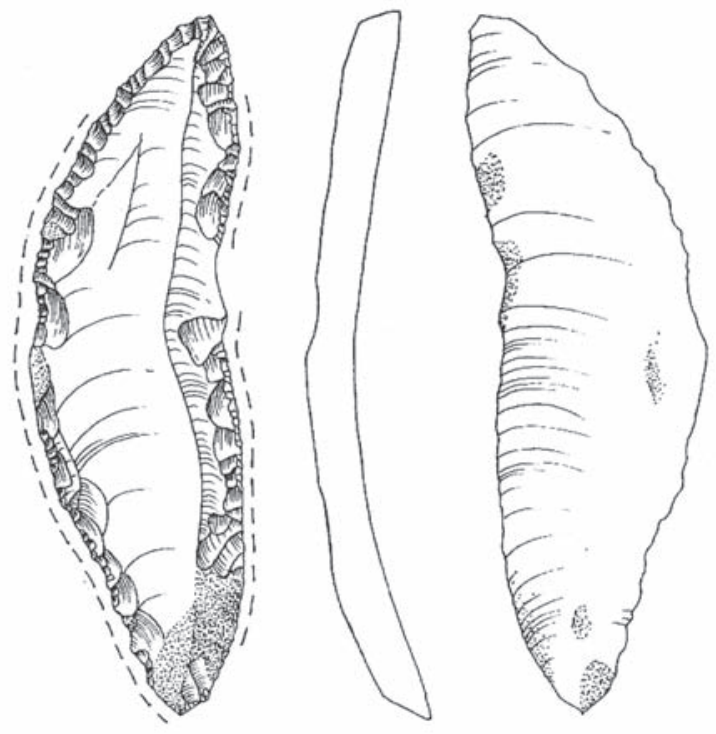

2

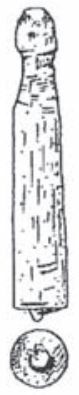

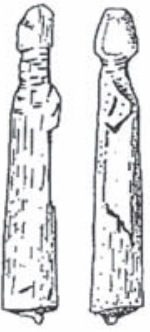

4

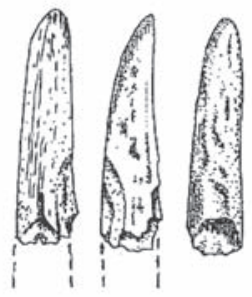

5

Ryc. 24. Jaskinia Deszczowa. Wybór wyrobów z epigraweckiego poziomu kulturowego: 1-3 - wiórowce kombinowane z pazurami; 4 - cylindryczny przedmiot rogowy; 5 - fragment ostrza kościanego (wg Cyrek i in. 2000)

Fig. 24. Deszczowa Cave. Examples of artefacts from epigravettian cultural level: 1-3-edges retouched blades combined with perforators; 4 - cylindrical antler object; 5 - fragment of a bone point (after Cyrek et al. 2000)

\section{Schytkowy paleolit}

Pojedyncze ślady pobytu człowieka w schyłkowym paleolicie znane są z północnej części Wyżyny Ryczowskiej, gdzie odkryto krótkotrwałe obozowiska identyfikowane z kulturami magdaleńską i epimagdaleńską (Cyrek 1994b; 2009; Cyrek i in. 2000) oraz świderską (Cyrek 2002). Najbardziej 


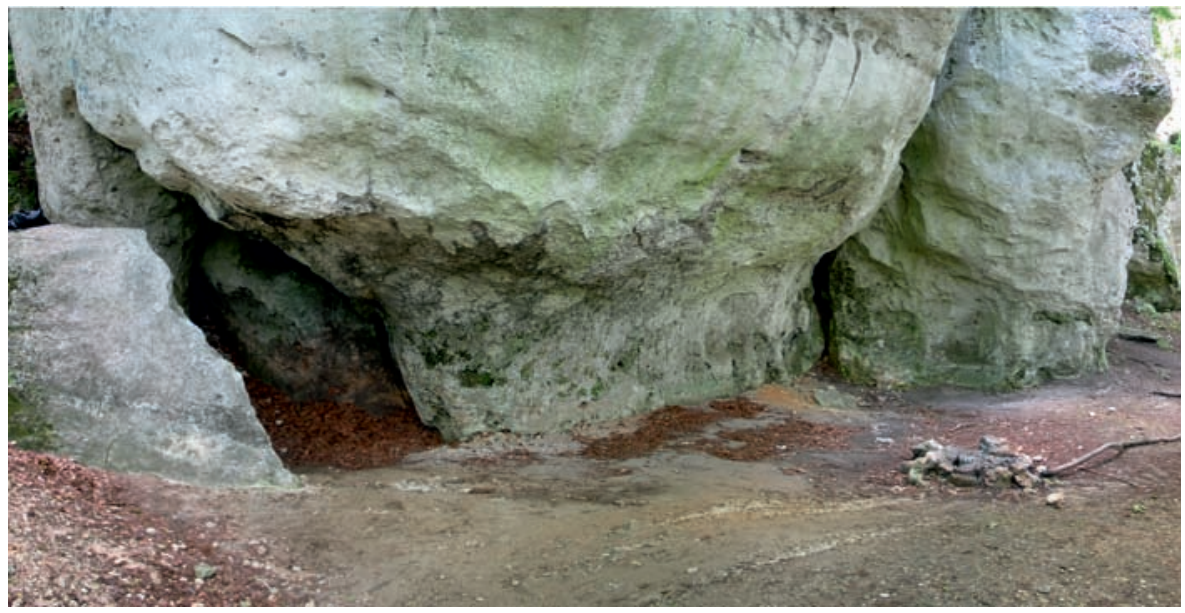

Ryc. 25. Schronisko Krucza Skała; widok ogólny (fot. M. Sudoł)

Fig. 25. Shelter in Krucza Skała; general view (photo M. Sudoł)

spektakularne odkrycia z tego okresu pochodzą ze Schroniska w Kruczej Skale (ryc. 25).

W zespole kultury magdaleńskiej, oprócz inwentarza krzemiennego (ryc. 26:1-9), znalazły się również przedmioty sztuki mobilnej (ryc. 27: 1,3). Ślady krótkotrwałego osadnictwa ludności kultury epimagdaleńskiej znane są również z Jaskini Deszczowej (Cyrek i in. 2000) oraz Jaskini Kroczyckiej (Cyrek 2009). Natomiast w Schronisku Ruska Skała w obrębie niewielkiego obozowiska kultury świderskiej, które na podstawie stratygrafii i danych przyrodniczych można datować na wczesny holocen, w pobliżu paleniska, wśród kilku wyrobów krzemiennych, znaleziono między innymi fragment ornamentowanej płytki rogowej (ryc. 27: 2) (Cyrek 2002).

W południowo-wschodniej części Wyżyny Ryczowskiej, w rejonie Gór Barańskich, do schyłkowego paleolitu nawiązują dwa otwarte stanowiska położone pomiędzy wsiami Cisowa i Kleszczowa, około $1 \mathrm{~km}$ na zachód od doliny Udorki (ryc. 28). Rdzenie (ryc. 29: 1, 2, 30: 1) oraz wiórowy półsurowiec (ryc. 30: 2, 3) zostały odkryte w sąsiedztwie fragmentu masywnego liściaka trzoneczkowatego lub przekłuwacza (ryc. 30: 4), co może oznaczać, że mamy do czynienia ze śladem penetracji tej okolicy przez łowców kultury świderskiej lub innej schyłkowopaleolitycznej jednostki kulturowej (być może magdaleńskiej?), w której inwentarzu spotykamy podobne formy. Prawdopodobnie z tym stanowiskiem łączyć można drugie, zlokalizowane przy wychodni krzemienia pasiastego w Sławniowie (Krajcarz, Sudoł i in. 2014).

Niejasną przynależność kulturową ma także paleolityczny ślad osadniczy uchwycony w Schronisku w Smoleniu III (ryc. 31) (Sudoł, Krajcarz 

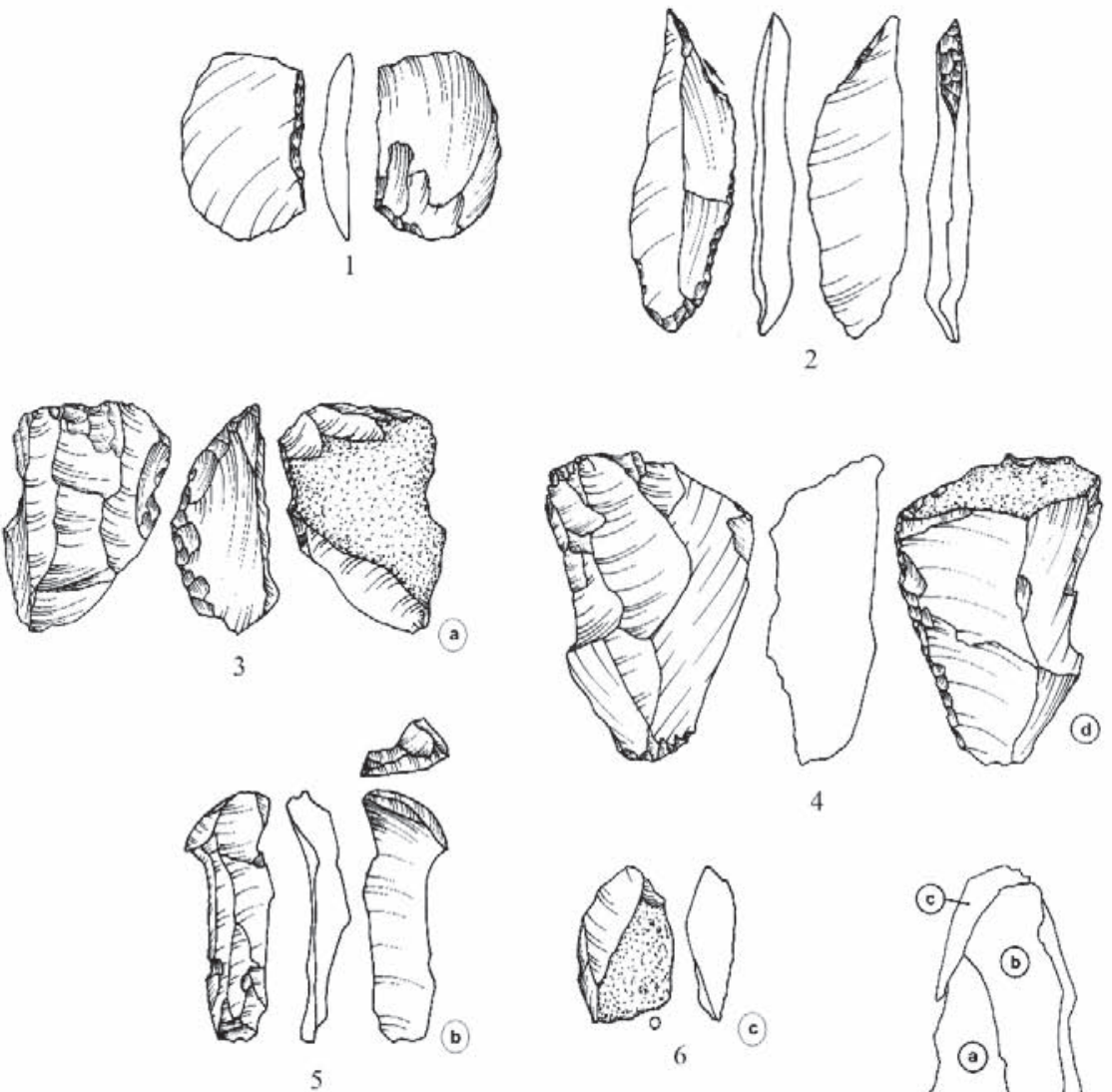

4
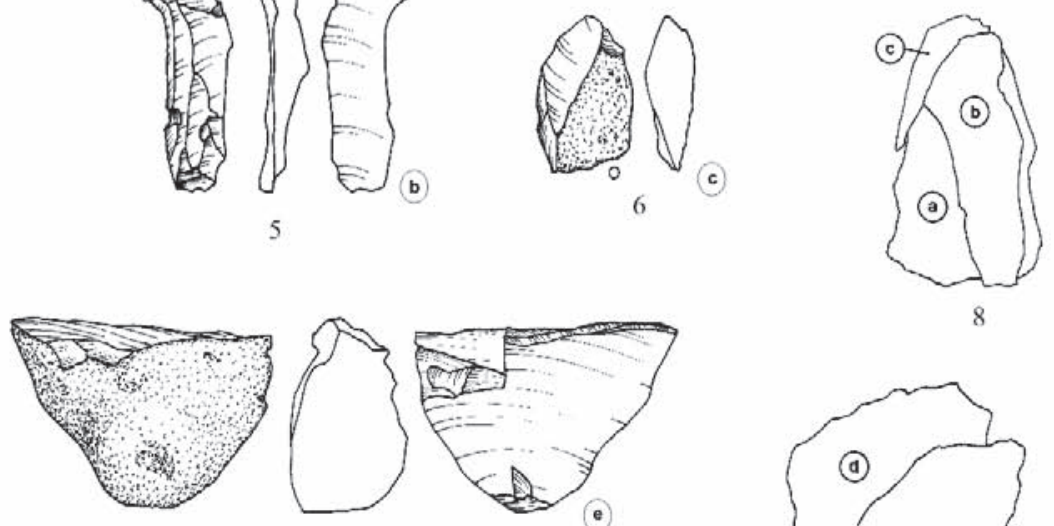

7

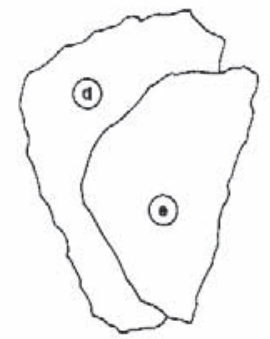

9

Ryc. 26. Schronisko Krucza Skała. Wybór wyrobów krzemiennych: 1 - tylczak z odłupka; 2 - półtylczak zdwojony; 3, 4-rdzenie; 5 - wiórek; 6-odłupek; 8, 9 - składanki (rys. M. Sudoł)

Fig. 26. Shelter in Krucza Skała. Examples of flint artefacts: 1 - backed edge flake; 2 -doubled semi-backed edge flake; 3, 4 - cores; 5 - blade; 6, 7 - flakes; 8,9 - reassembling (drawn M. Sudoł) 

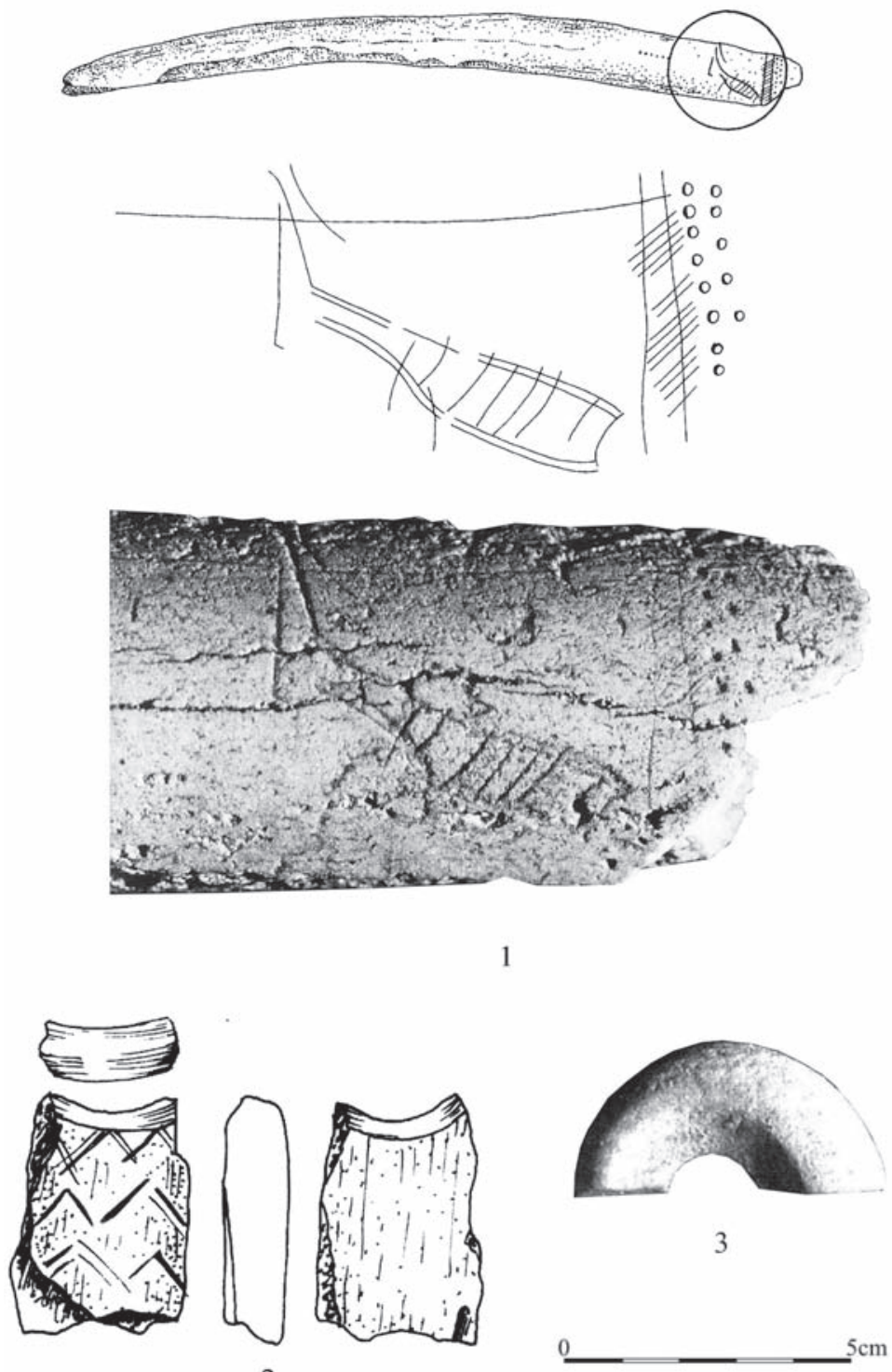

2

Ryc. 27. Przedmioty sztuki mobilnej ze Schroniska Krucza Skała $(1,3)$ oraz Ruska Skała (2): 1 - fragment poroża z zoomorficznym i geometrycznym rytem (baquette demi - ronde); 2 - ornamentowana płytka rogowa; 3 - fragment paciorka $\mathrm{z}$ amonitu (za 1 - wg Cyrek 1994c; 2, 3 - wg Cyrek 2002)

Fig. 27. Objects of portable art from Shelter in Krucza Skała $(1,3)$ and Shelter in Ruska Skała (2): 1 - fragment of antlers with zoomorphic and geometrical etching (baquette demi-ronde); 2 - ornamented horn plaque; 3 - fragment of amonito bead (1-after Cyrek 1994c; 2, 3 - after Cyrek 2002) 


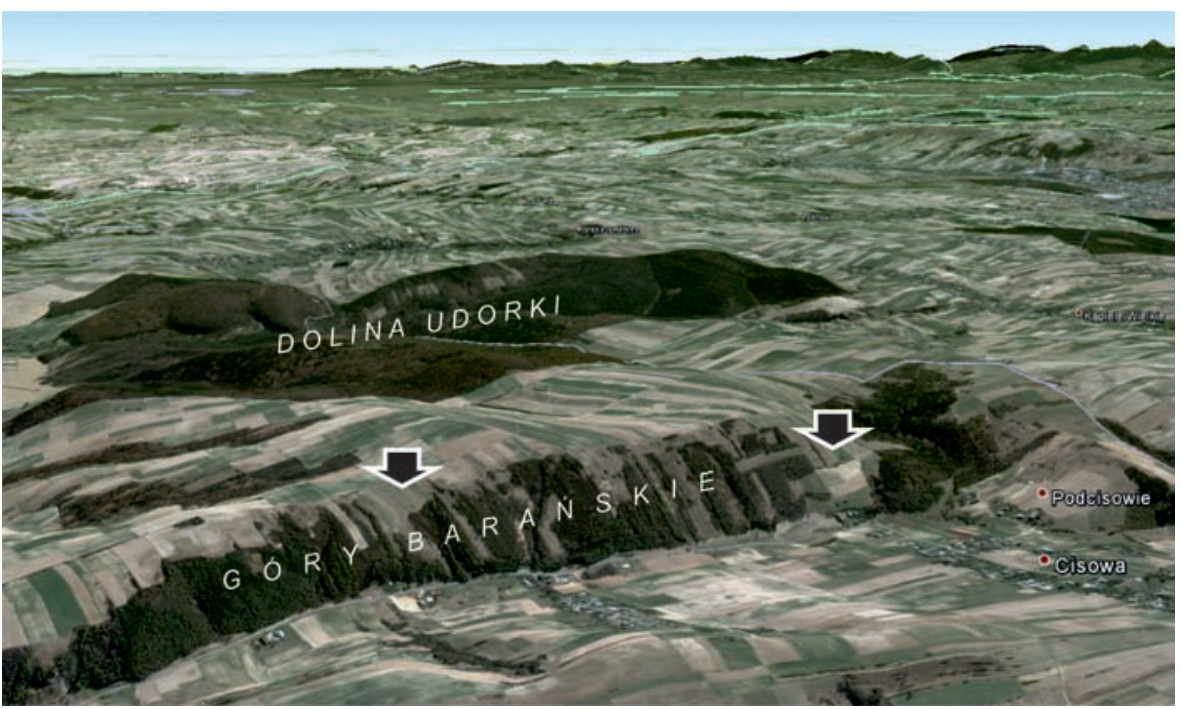

Ryc. 28. Lokalizacja schyłkowopaleolitycznych stanowisk otwartych Kleszczowa i Sławniów w pobliżu wsi Cisowa w Górach Barańskich, (źródło: Google Earth)

Fig. 28. Location of Late Paleolithic open-air sites from Kleszczowa and Sławinów near Cisowa village in Barańskie Mountains (source: Google Earth)

2014). W okolicy paleniska (ryc. 32: 1) uchwyconego w lessowej warstwie, wystąpiły lekko rozmyte węgle i pył węglowy, a także kość długa łosia (ryc. 32: 2). Nie natrafiono na artefakty krzemienne, a materiał faunistyczny był bardzo ubogi. Klimat panujący podczas sedymentacji warstwy, w której odsłonięto palenisko, na podstawie pojedynczych szczątków gryzoni, został określony jako krótkotrwałe ocieplenie podczas bardzo zimnego okresu. Datowanie metodą termoluminescencyjną (TL) łączą ten obiekt z okresem przejściowym pomiędzy interpleniglacjałem a młodszym pleniglacjałem (OIS 3/2). Mógłby to więc być ślad krótkiego pobytu górnopaleolitycznych łowców, najprawdopodobniej związanych z kompleksem graweckim, którego pozostałości znamy z pobliskiej Jaskini Jasnej Strzegowskiej. Jednakże daty radiowęglowe uzyskane dla węgli z paleniska, a także z kości długiej łosia, wskazują na okres późniejszy, związany z penetracją tego regionu przez schyłkowopaleolitycznych łowców (Krajcarz i in. 2015). Różnice w datowaniu można wyjaśnić tym, że datowanie TL dotyczy momentu eolicznej sedymentacji lessów i nie musi być tożsame z ostateczną depozycją osadu, ani z późniejszym śladem pobytu w tym miejscu człowieka (jak wskazują datowania radiowęglowe). Datowania radiowęglowe dotyczą bezpośrednio składników poziomu kulturowego i w związku z tym są bardziej wiarygodnym wskaźnikiem jego wieku. 

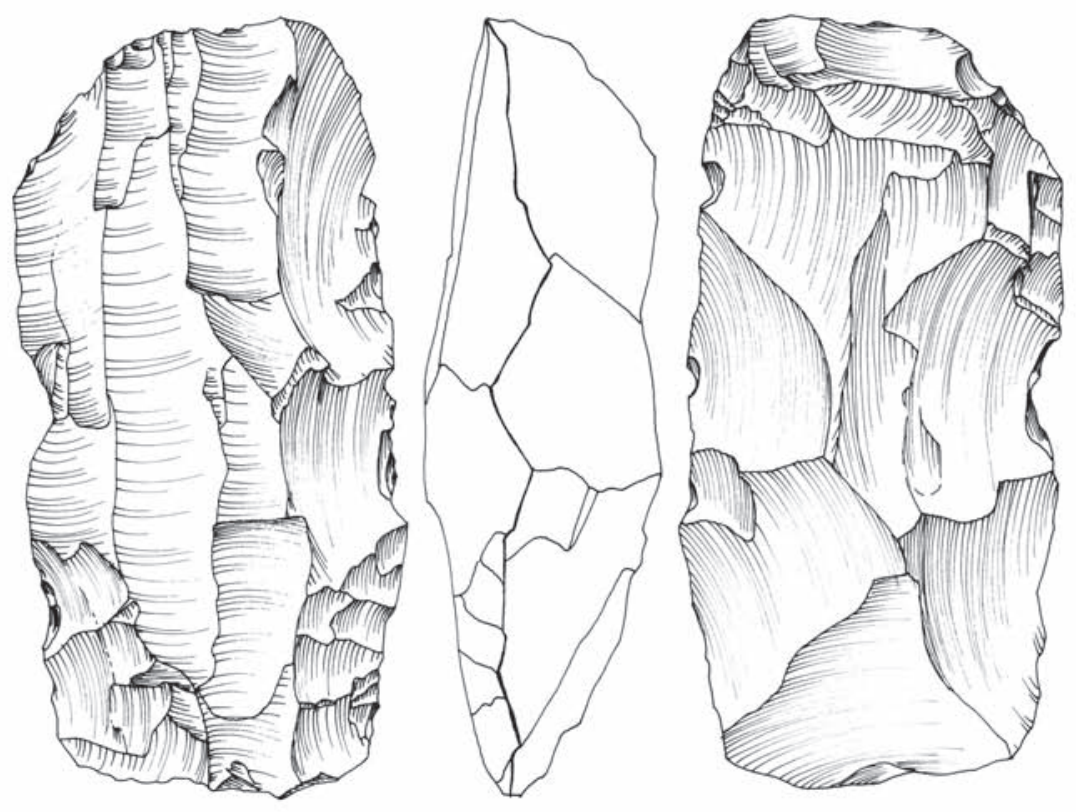

1
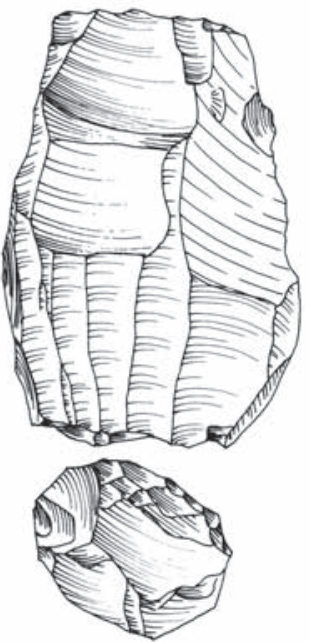
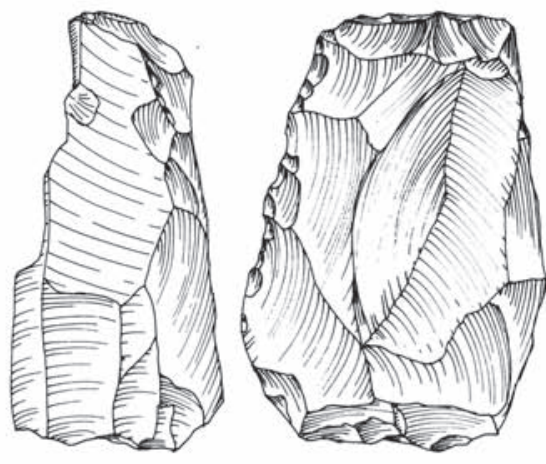

2
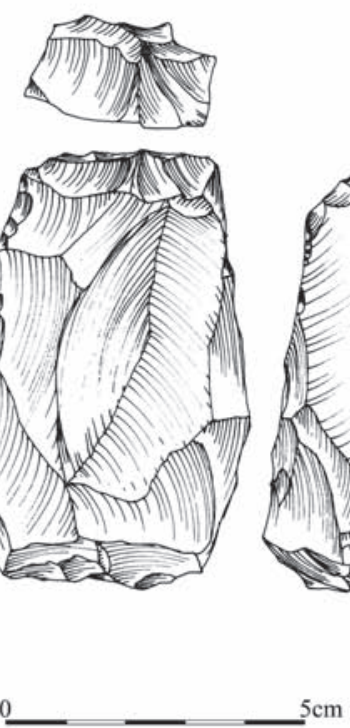

Ryc. 29. Wybór wyrobów krzemiennych z Gór Barańskich: 1, 2 - rdzenie (wg Sudoł i in. 2016)

Fig. 29. Examples of flint artefacts from Barańskie Mountains: 1, 2-cores (after Sudoł et al. 2016) 

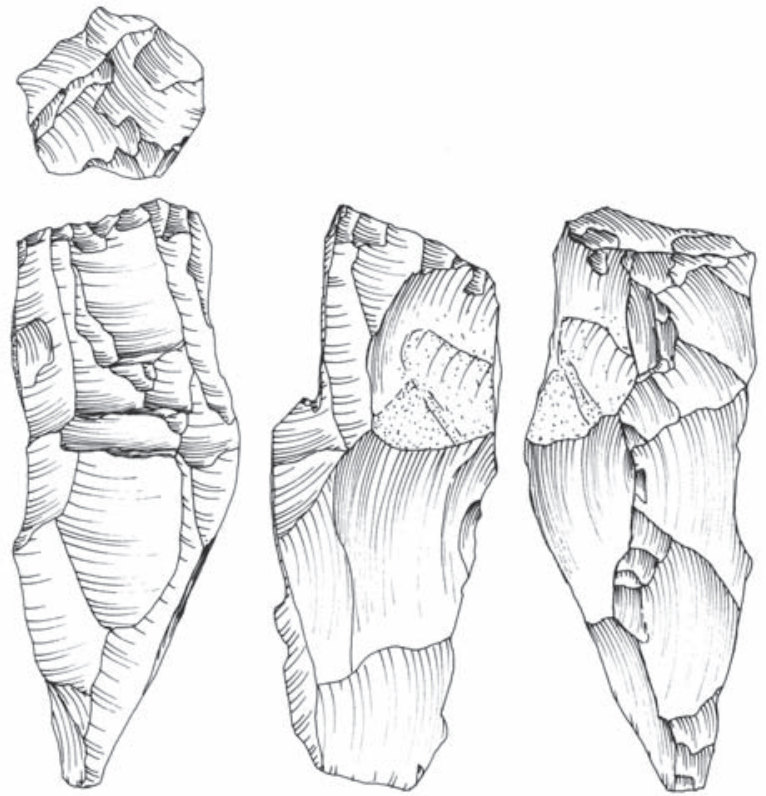

1
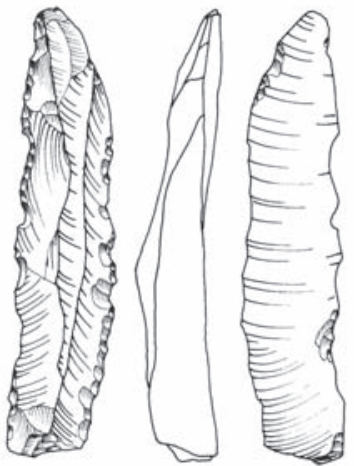

2
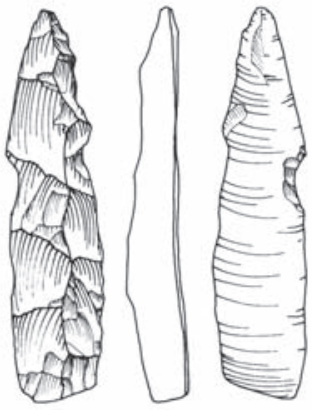

3

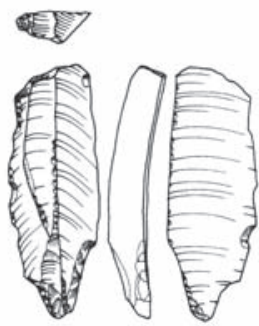

4

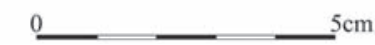

Ryc. 30. Góry Barańskie. Wybór wyrobów krzemiennych: 1 -rdzeń; 2, 3 -wióry techniczne; 4 - liściak lub przekłuwacz (wg Sudoł $\mathrm{i}$ in. 2016)

Fig. 30. Barańskie Mountains. Examples of flint artefacts: 1 - core; 2, 3 - technical blades; 4 - tanged point or perforator (after Sudoł et al. 2016) 


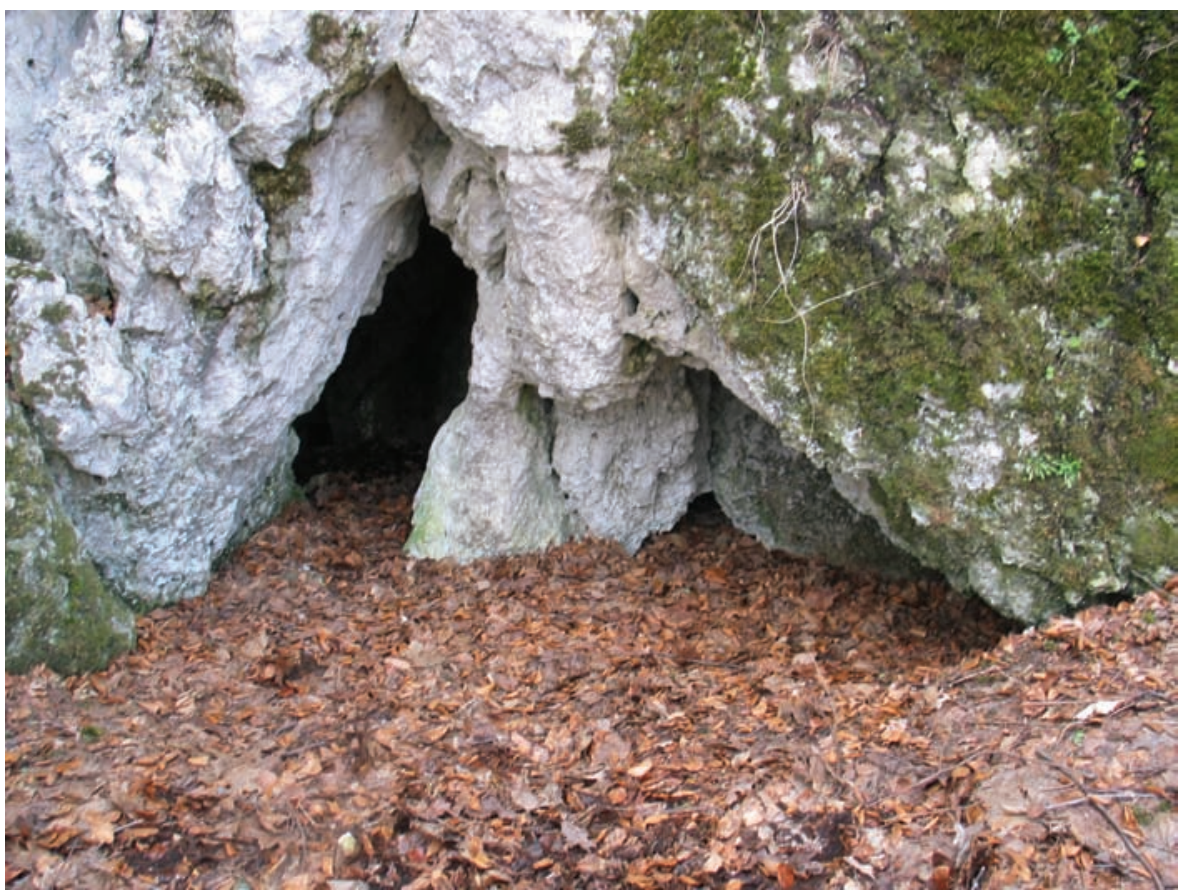

Ryc. 31. Schronisko w Smoleniu III; widok na otwór wejściowy (fot. M. Sudoł)

Fig. 31. Shelter in Smoleń III; general view (photo M. Sudoł)

\section{WNIOSKI}

Osadnictwo paleolityczne na Wyżynie Ryczowskiej, jak pokazują dotychczasowe badania, jest reprezentowane we wszystkich fazach paleolitu. Prawdopodobnie jest to związane z korzystnymi uwarunkowaniami paleośrodowiskowymi, w tym surowcowymi i geomorfologicznymi (Sudoł i in. 2016). Warte odnotowania jest zróżnicowanie charakteru osadnictwa w poszczególnych rejonach Wyżyny Ryczowskiej (ryc. 33). W południowej jej części zwraca uwagę różna sytuacja zasiedlenia w starszych i młodszych okresach paleolitu.

Dotychczasowe badania w Jaskini Biśnik umożliwiły dokładne rozpoznanie charakteru osadnictwa w środkowym paleolicie. Miejsce to było odwiedzane często, jednak najbardziej intensywnie pod koniec wspomnianego okresu, o czym świadczy liczebność najmłodszych środkowopaleolitycznych inwentarzy D, E i F. Taka sytuacja sugeruje, że jaskinia we wczesnym vistulianie i w starszej fazie interplenivistulianu mogła pełnić rolę obozowiska 

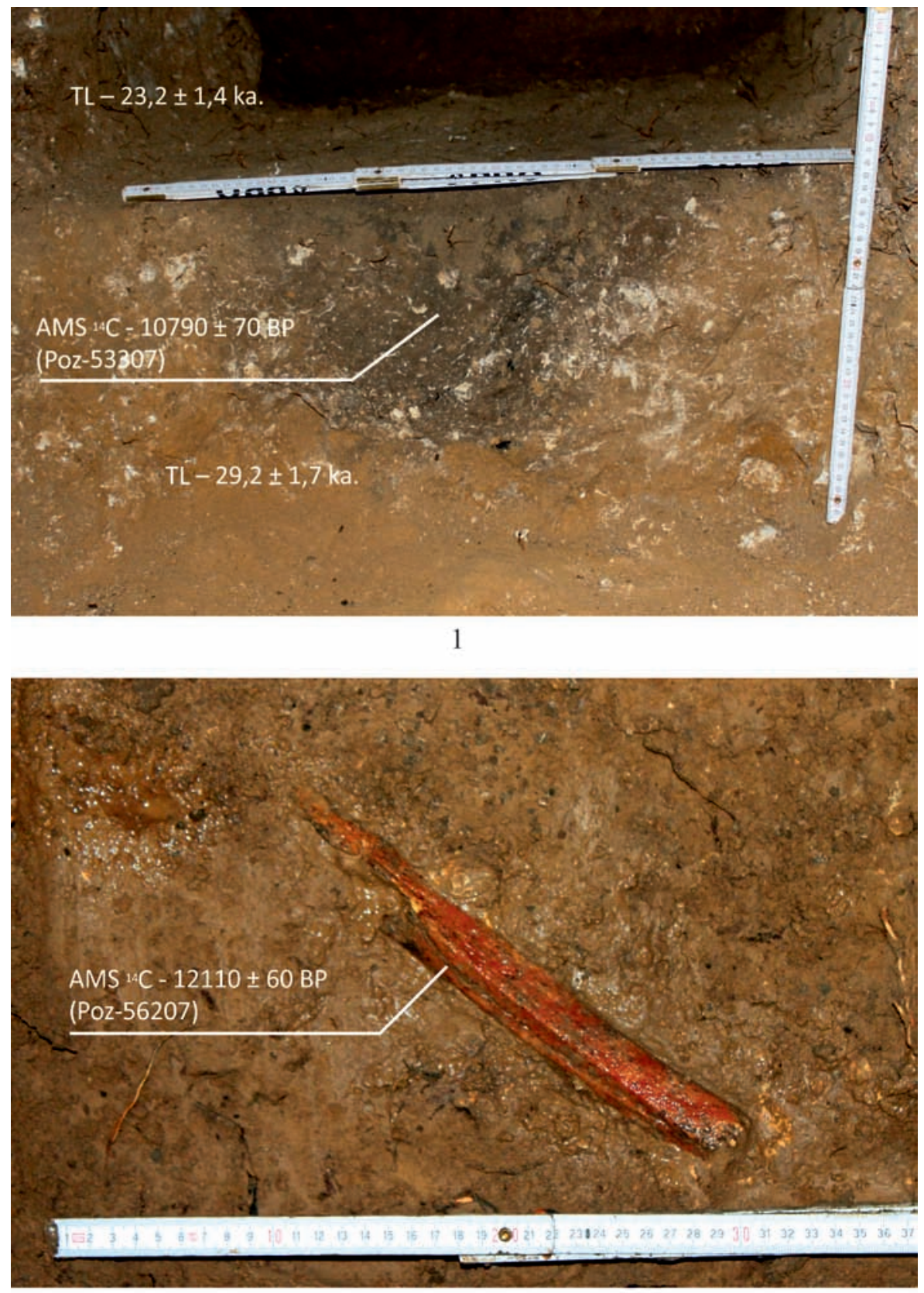

2

Ryc. 32. Schronisko w Smoleniu III. Relikty osadnictwa schyłkowopaleolitycznego: 1 - przekrój paleniska; 2 - kość długa łosia (wg Sudoł i in. 2016)

Fig. 32. Shelter in Smolen III. Relics of Lower Paleolithic settlement: 1 - traces of hearths; 2 - long bone of elk (after Sudoł et al. 2016) 


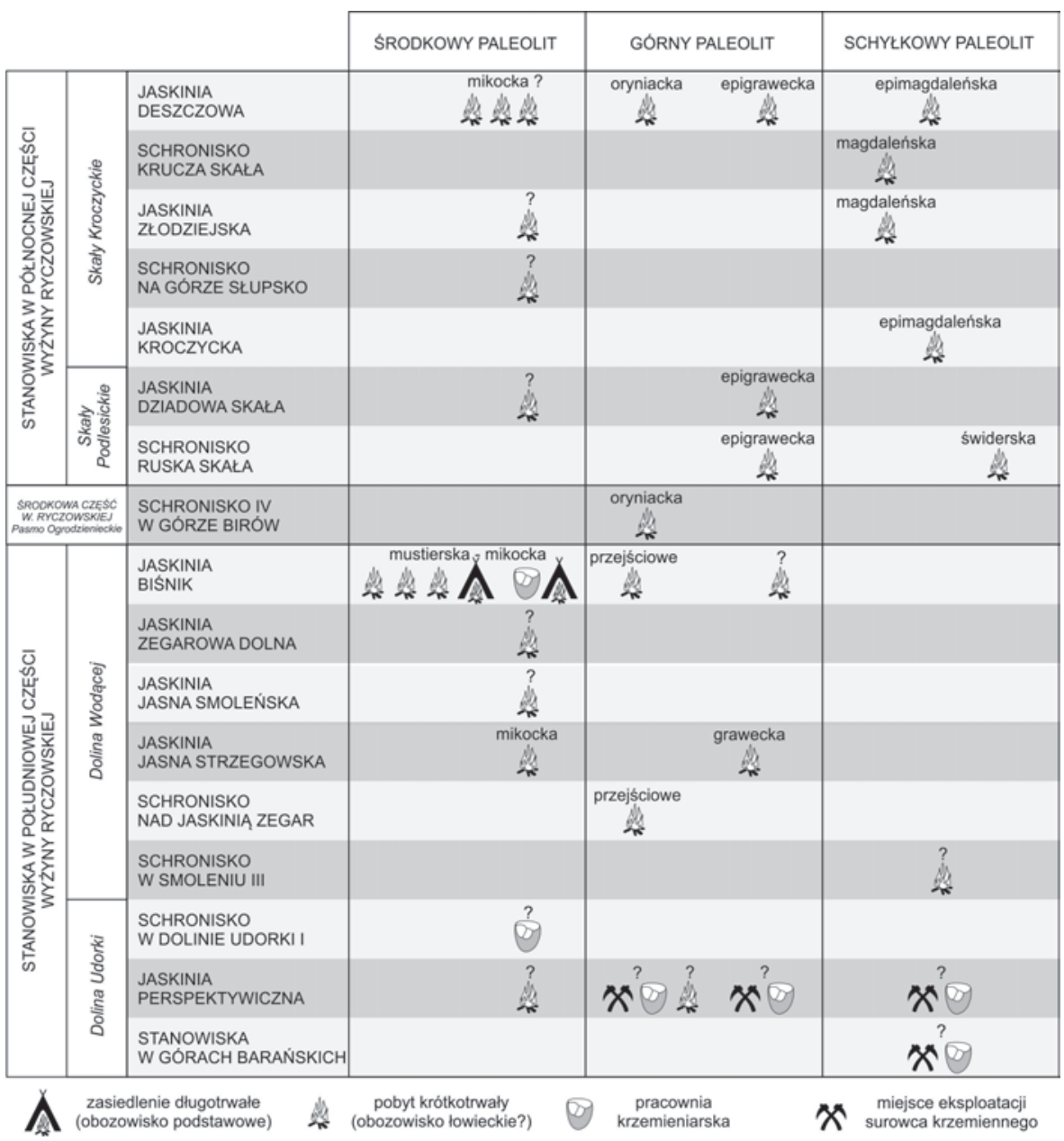

Ryc. 33. Paleolityczne poziomy kulturowe na stanowiskach z Wyżyny Ryczowskiej (wg Sudoł i in. 2016, ze zmianami)

Fig. 33. Paleolithic cultural levels in sites of Ryczów Upland (after Sudoł et al. 2016, with changes)

podstawowego, a ubogie ślady z tego okresu w innych okolicznych jaskiniach i schroniskach być może są śladem łowieckich penetracji. Stanowiska z młodszej fazy interplenivistulianu i z późnego vistulianu (paleolit górny i środkowy) w południowej części rejonu mają charakter pracowni i zlokalizowane są w bezpośrednim sąsiedztwie wychodni surowców dobrej jakości (np. krzemienia czekoladowego w rejonie doliny Udorki, czy krzemienia pasiastego w rejonie Gór Barańskich) (Krajcarz, Sudoł i in. 2014; Sudoł i in. 2016). Natomiast osadnictwo w północnym rejonie Wyżyny, pozbawionym 
wychodni dobrego surowca krzemiennego, to ślady krótkotrwałych obozowisk funkcjonujących we wszystkich okresach paleolitu.

Jak wynika z powyższych uwag w środkowym paleolicie przy wyborze jaskini jako miejsca zasiedlenia większe znaczenie przywiązywano do innych aspektów krajobrazu niż obecność dobrych surowców mineralnych. Prawdopodobnie istotne mogły być takie cechy jak: morfologia i struktura obiektu, usytuowanie względem dna doliny, liczba, wielkość i ekspozycja otworów wejściowych, bliskość wody i związana z tym dostępność do zwierzyny łownej. W większości inwentarzy środkowopaleolitycznych dominuje gorszy w obróbce surowiec, dostępny w najbliższym sąsiedztwie obozowisk. Nie zmienia to faktu, że człowiek neandertalski doceniając bardzo dobre walory krzemienia, wykorzystywał go również do produkcji narzędzi, głównie bifacjalnych, korzystając z wychodni oddalonych od obozowiska od 5 do 10 km (Krajcarz i in. 2012a; 2014; Sudoł i in. 2016). Analiza surowcowa lokalnych odmian krzemieni wskazuje na większy udział surowców bardzo dobrej jakości w inwentarzach górno- i schyłkowopaleolitycznych niż w środkowopaleolitycznych. W południowej części Wyżyny były to głównie: lokalny krzemień „czekoladowy”, lokalny krzemień pasiasty oraz krzemień z Wierbki (Krajcarz i in. 2012a). W ich bezpośrednim sąsiedztwie odkrywane są otwarte obozowiska (pozostałości pracowni krzemieniarskich), pomimo braku naturalnych schronień skalnych czy bezpośredniego dostępu do cieków wodnych (Sudoł $\mathrm{i}$ in. 2016).

Dalsze interdyscyplinarne badania z pewnością pozwolą lepiej zrozumieć powody wyboru określonych miejsc na paleolityczne obozowiska oraz pełniej zrekonstruować relacje pomiędzy kulturą a środowiskiem przyrodniczym penetrowanej przez człowieka przestrzeni.

\section{LITERATURA}

Wykaz skrótów

Karst of the Częstochowa Upland - $\quad$ Karst of the Częstochowa Upland and of the Eastern Sudetes. Palaeoenvironments and protection, red. K. Stefaniak, A. Tyc, P. Socha, Studies of the Faculty of Earth Sciences University of Silesia, nr 56, Sosnowiec-Wrocław. 
Chmielewska M., Pierzchałko Ł.

1956 Stanowisko wczesnomezolityczne w schronisku skalnym koło Podlesic w pow. Zawierciańskim, Prace i Materiały Muzeum Archeologicznego i Etnograficznego w Łodzi, seria archeologiczna, nr 1, s. 29-40.

Chmielewski W.

1958 Stanowisko paleolityczne w Dziadowej Skale koło Skarżyc w pow. Zawierciańskim, Prace i Materiały Muzeum Archeologicznego i Etnograficznego w Lodzi, seria archeologiczna, nr 3, s. 5-48.

1967 Plejstoceńskie i wczesnoholoceńskie kultury archeologiczne Polski, [w:] Czwartorzęd Polski, Warszawa, s. 83-105.

1975 Paleolit środkowy i górny, [w:] Prahistoria ziem polskich, t. 1: Paleolit i mezolit, red. W. Chmielewski, W. Hensel, Wrocław, s. 9-158.

1988 Ogólna charakterystyka jaskiń Doliny Saspowskiej pod względem występowania w nich źródeł archeologicznych, [w:] Jaskinie Doliny Saspowskiej. Tto przyrodnicze osadnictwa pradziejowego, red. W. Chmielewski, Prace Instytutu Archeologii Uniwersytetu Warszawskiego, t. 1, Warszawa, s. 5-17.

Cyrek K.

1994a Wyniki badań sondażowych na Górze Stupsko (stanowisko 3) w Kostkowicach, województwo częstochowskie, [w:] Badania archeologiczne na Górnym Śląsku i w Zagłębiu Dąbrowskim w latach 1991-1992, red. E. Tomczyk, Katowice, s. 26-33.

1994b Wyniki badań wykopaliskowych w schronisku skalnym Krucza Skała (stanowisko 1) w Kostkowicach, województwo częstochowskie, w 1991 roku, [w:] Badania archeologiczne na Górnym Śląsku i w Zagłębiu Dabrowskim w latach 1991-1992, red. E. Tomczyk, Katowice, s. 34-42.

1994c Der Jungpaläolitische Höhlenfundplatz Krucza Skała in Mittelpolen, Archäologisches Korrespondenzblatt, t. 24, z. 4, s. 367-374.

1997 Wyniki badań sondażowych przed jaskinia Kroczycka (stanowisko 3) w Kostkowicach, województwo częstochowskie, [w:] Badania archeologiczne na Górnym Ślasku i w Zagłębiu Dąbrowskim w 1993 roku, red. E. Tomczyk, Katowice, s. 67-71.

2002 Plastyka paleolityczna z jaskiń i schronisk pólnocnej części Wyżyny Krakowsko-Częstochowskiej, [w:] Sztuka pradziejowa ziem polskich. Katalog wystawy, red. T. Janiak, Gniezno, s. 41-46.

2009 Archaeological studies in caves of the Częstochowa Upland, [w:] Karst of the Częstochowa Upland, s. 145-160.

2013 Jaskinia Biśnik. Wczesny środkowy paleolit, Torun. 
Cyrek K., Nadachowski A., Madeyska T., Bocheński Z., Tomek T., Wojtal P., Miękina B., Lipecki G., Garapich A., Rzebik-Kowalska B., Stworzewicz E., Wolsan M., Godawa J., Kościów R., Fostowicz-Frelik L., Szyndlar Z.

2000 Excavation in the Deszczowa Cave (Kroczyckie Rocks, Częstochowa Upland, Central Poland), Folia Quaternaria, t. 71, s. 5-84.

Cyrek K., Socha P., Stefaniak K., Madeyska T., Mirosław-Grabowska J., Sudoł M., Czyżewski Ł.

2010 Palaeolithic of Biśnik Cave (southern Poland) within the environmental background, Quaternary International, t. 220, s. 5-30 (DOI: 10.1016/j. quaint.2009.09.014).

Cyrek K., Sudoł M., Czyżewski Ł. A., Osipowicz G., Grelowska M.

2014 Middle Palaeolithic cultural levels from Middle and Late Pleistocene sediments of Biśnik Cave, Poland, Quaternary International, t. 326-327, s. 20-63 (DOI: 10.1016/j.quaint.2013.12.014).

Jaskinia Biśnik

2002 Jaskinia Biśnik. Rekonstrukcja zasiedlenia jaskini na tle zmian środowiska przyrodniczego, red. K. Cyrek, Toruń.

Kowalski K.

1951 Jaskinie Polski, t. 1, Warszawa.

Kozłowski S. K.

2007 Stefan Krukowski. Narodziny giganta, Studia nad gospodarką surowcami krzemiennymi w pradziejach, t. 6, Warszawa, s. 63-71.

Krajcarz M., Wojenka M., Krajcarz M. T., Cyrek K.

2014 Wyniki badań wykopaliskowych w Schronisku na Górze Stupsko w Kostkowicach oraz Jaskini Deszczowej w Kostkowicach, województwo śląskie, [w:] Badania archeologiczne na Górnym Ślasku i ziemiach pogranicznych w latach 2011-2012, red. G. Glanc-Zagaja, Katowice, s. 22-29.

Krajcarz M. T., Bosák P., Šlechta S., Pruner P., Komar M., Dresler J., Madeyska T.

2014 Sediments of the Biśnik Cave (Poland): lithology and stratigraphy of the Middle Palaeolithic site, Quaternary International, t. 326-327, s. 6-19 (DOI: 10.1016/j.quaint.2013.10.017).

Krajcarz M. T., Cyrek K.

2011 The age of the oldest Paleolithic assemblages from Biśnik Cave (southern Poland) in the light of geological data, Przegląd Archeologiczny, t. 59, s. 55-74.

Krajcarz M. T., Cyrek K., Krajcarz M., Mroczek P., Sudoł M., Szymanek M., Tomek T., Madeyska T.,

2015 Loess in a cave - Lithostratigraphic and correlative value of loess and loess-like layers in caves from the Kraków-Częstochowa Upland (Poland), Quaternary International (in press, doi: 10/1016/j. quaint.2015.08.069). 
Krajcarz M. T., Krajcarz M., Sudoł M., Cyrek K.

2012 From far or from near? Map of silicate raw material outcrops around the Biśnik Cave, [w:] Abstract Book and excursion guide, $9^{\text {th }}$ SKAM Workshop Moravian Museum, Brno, Czech Republic, October 8-11, 2012 Lithic Raw Materials - Phenomena of the Stone Age, red. P. Neruda, Z. Nerudová, Brno, s. 15-16.

Krajcarz M. T., Sudoł M., Krajcarz M., Cyrek K.

2012a From far or from near? Sources of Kraków-Częstochowa banded and chocolate silicite raw material used during the Stone Age in Biśnik Cave (southern Poland), Anthropologie. International Journal of the Science of Man, t. 50, z. 4, s. 411-425.

2012b Stanowisko późnoczwartorzędowych osadów jaskiniowych - Schronisko nad Jaskinia Zegar w Skałach Zegarowych (Wyżyna Częstochowska), Przegląd Geologiczny, t. 60, z. 10, s. 546-553.

2014 Wychodnie krzemienia pasiastego na Wyżynie Ryczowskiej (Wyżyna Krakowsko-Częstochowska), [w:] Górnictwo z epoki kamienia: Krzemionki-Polska-Europa. W 90. rocznicę odkrycia kopalni w Krzemionkach, red. D. Piotrowska i in., Ostrowiec Świętokrzyski, s. 225-244.

Madeyska T.

2006 Tlo przyrodnicze osadnictwa pradziejowego Jury Ojcowskiej, [w:] Jura Ojcowska w pradziejach i w początkach państwa polskiego (The Ojców Jura in prehistory and in the beginning of the Polish state), red. J. Lech, J. Partyka, Ojców, s. 270-312.

Mirosław-Grabowska J., Cyrek K.

2009 Archaeology and statigraphy of the Jasna Strzegowska Cave, [w:] Karst of the Częstochowa Upland, s. 273-282.

Muzolf B.

1994 Wielokulturowe stanowisko archeologiczne na Górze Birów w Podzamczu województwo katowickie w 1992 roku, [w:] Badania archeologiczne na Górnym Śląsku i w Zagłębiu Dąbrowskim w latach 1992-1993, red. E. Tomczyk, Katowice, s. 259-269.

1997a Walory Doliny Wodącej w rejonie miejscowości Smoleń-Strzegowa. 7. Sympozjum Jurajskie „Człowiek i środowisko naturalne Wyżyny Krakowsko-Wieluńskiej”, wyd. Zarząd Zespołu Jurajskich Parków Krajobrazowych, Dąbrowa Górnicza, s. 51-58.

1997b Badania na Skale Grodzisko Pańskie w Strzegowej, województwo katowickie, [w:] Badania archeologiczne na Górnym Śląsku i w Zaglębiu Dąbrowskim w 1994 roku, red. E. Tomczyk, Katowice, 155-161.

1997c Sprawozdanie z badań na Skale Biśnik w Strzegowej, województwo katowickie, [w:] Badania archeologiczne na Górnym Śląsku i w Zagłębiu Dąbrowskim w 1994 roku, red. E. Tomczyk, Katowice, s. 144-153. 
1997d Badania kompleksu stanowisk na Górze Birów w Podzamczu województwo katowickie, [w:] Badania archeologiczne na Górnym Śląsu i w Zagtębiu Dąbrowskim w 1993 roku, red. E. Tomczyk, Katowice, s. 44-47.

1997e Badania wielokulturowego stanowiska na Górze Birów w Podzamczu województwo katowickie, [w:] Badania archeologiczne na Górnym Ślasku i w Zagłębiu Dąbrowskim w 1994 roku, red. E. Tomczyk, Katowice, s. 119-129.

Muzolf B., Stefaniak K., Tomek T., Wertz K., Socha P., Cyrek K., Mirosław-Grabowska J., Madeyska T.

2009 Multiculture sites on Mt. Birów in Podzamcze, [w:] Karst of the Częstochowa Upland, s. 283-294.

Muzolf B., Śnieszko Z., Wiszniowska T.

1999 Jaskinie kompleksu Skat Zegarowych, [w:] Materiaty 33 Sympozjum Speleologicznego, Jeziorowice 22-24. 10. 1999, red. A. Tyc, Kraków, s. $8-12$.

Pelisiak A.

1993-1994 Jaskinia Biśnik (gmina Wolbrom, woj. katowickie) - badania z 1991 roku, Acta Archaeologica Carpathica, t. 32, s. 125-150.

2003 Ze studiów nad wykorzystywaniem surowców krzemiennych ze środkowej części Wyżyny Krakowsko-Częstochowskiej w późnym neolicie w strefie karpackiej. Neolityczne pracownie w Strzegowej (Strzegowa, stan. 42), Acta Archaeologica Carpathica, t. 38, s. 27-69.

2006 The Exploitation and Distribution of Flints From the Central Part of Polish Jura in the Late Neolithic Times, Analecta Archaeologica Ressoviensia, t. 1, s. 73-86.

Rybicka M., Cyrek K.

1997 Wyniki weryfikacyjnych badań wykopaliskowych w Jaskini Jasnej w Strzegowej, woj. katowickie, w 1991 roku, Lódzkie Sprawozdania Archeologiczne, t. 3, s. 5-16.

Sawicki L.

1953 Stan badań nad wiekiem człowieka kopalnego, Acta Geologica Polonica, t. 3, z.1, s. 171-189.

Stefaniak K., Muzolf B., Mirosław-Grabowska J., Socha P.

2009 Studies in the caves of the Zegarowe Rocks, [w:] Karst of the Częstochowa Upland, s. 255-272.

Sudoł M.

2013 Kultura mikocka na ziemiach polskich, maszynopis rozprawy doktorskiej w Instytucie Archeologii UMK, Torun.

Sudoł M., Cyrek K., Krajcarz M., Krajcarz M. T.

2016 Around the Biśnik Cave - the area of human penetration during the Palaeolithic, Anthropologie, t. 54/1, s. 49-68. 
Sudoł M., Cyrek K., Krajcarz M. T., Krajcarz M.

2013 Wokół Jaskini Biśnik: potencjalna przestrzeń penetrowana przez człowieka w paleolicie, [w:] Artefakt w przestrzeni: krzemienica, skupienie, stanowisko, region. 10. warsztaty kamieniarskie SKAM, 23-25 października 2013, Toruń, Polska. Książka streszczeń, Toruń, s. 46-48.

Sudoł M., Krajcarz M. T., Krajcarz M.

2013 Jaskinia Perspektywiczna - nowe stanowisko paleolityczne $w$ dolinie Udorki (Wyżyna Częstochowska), [w:] Materiały 47. Sympozjum Speleologicznego, Olsztyn, 17-20.10.2013 r., red. A. Tyc, M. Gradziński, Kraków, s. 75-76.

Sudoł M., Krajcarz M. T.

2014 Wyniki badań sondażowych w Schronisku w Górze Smoleń II oraz Schronisku w Smoleniu III w Smoleniu, gm. Pilica, województwo ślaskie, w roku 2012, [w:] Badania archeologiczne na Górnym Śląsku i ziemiach pogranicznych w latach 2011-2012, red. G. Glanc-Zagaja, Katowice, s. 13-21.

\section{PALEOLITHIC SETTLEMENT IN RYCZOWSKA UPLAND (CENTRAL PART OF CZESTOCHOWA HIGHLAND)}

\section{Summary}

Paleolithic period's presence in Ryczowów Upland is reported in very few sites, with the most significant - Biśnik Cave in Wodąca Valley, where over 21 settlement levels of Middle Paleolithic have been registered and Deszczowa Cave, Shelter in Krucza Skała in Korczyckie Rocks, which delivered Upper- and Lower Paleolithic flint assemblages. Basing on recent research results, we obtain more detailed picture of Ryczów Upland settlement, its southern part in particular. The article's purpose is to present in synthetic form Paleolithic settlement of that micro-region and its coexistence with several aspects of natural environment in subsequent stages of the area settling.

Translated by Ewa Józefowicz

Adres do korespondencji:

Magdalena Sudot, Krzysztof Cyrek

Instytut Archeologii, Uniwersytet Mikolaja Kopernika w Toruniu

ul. Szosa Bydgoska 44/48, 87-100 Toruń;

sudol@umk.pl,paleo@umk.pl 